VALADARES, RN; MELO, RA; SARINHO, IVF; OLIVEIRA, NS; ROCHA, FAT; SILVA, JW; MENEZES, D. 2018. Genetic diversity in accessions of melon belonging to momordica group. Horticultura Brasileira 36: 253258. DOI: http://dx.doi.org/10.1590/S0102-053620180218

\title{
Genetic diversity in accessions of melon belonging to momordica group
}

\author{
Ricardo N Valadares ${ }^{1}$; Roberto A Melo ${ }^{1}$; Isabel VF Sarinho ${ }^{1}$; Natália S Oliveira ${ }^{2}$; Fernando AT Rocha ${ }^{1}$; \\ José W Silva ${ }^{1}$; Dimas Menezes ${ }^{1}$
}

${ }^{1}$ Universidade Federal Rural de Pernambuco (UFRPE), Recife-PE, Brazil; rnvaladares@yahoo.com.br (corresponding author); robertoagronomo@yahoo.com.br; isabelsarinho@gmail.com; fernandortrecife@hotmail.com; jwsamaral@hotmail.com; dimasmenezes@ superig.com.b; ${ }^{2}$ Universidade Federal de Lavras (UFLA), Lavras-MG, Brazil; natalia.agro@yahoo.com.br

\begin{abstract}
The genetic divergence of melon genotypes belonging to momordica group, collected in five Brazilian States, was estimated, and the relative contribution of the morphological characters was determined for the genetic variability. The experimental design was randomized blocks, with four replicates. We evaluated 19 accessions of melon, momordica group, two accessions of cantaloupensis group and two commercial cultivars of inodorus group. These genotypes were characterized by 42 morphological descriptors. The data were submitted to Tocher and UPGMA grouping methods using the genetic dissimilarity matrix, using Mahalanobis' distance. Singh criterion was used to identify the relative contribution of each character to the genetic divergence. Four groups of similarity were obtained in both multivariate techniques, with agreement between hierarchical UPGMA and Tocher grouping methods. The characters: pistil scar size, soluble solid content, seed length, fruit length and cotyledon length contributed with approximately $53.86 \%$ to genetic divergence among genotypes.
\end{abstract}

Keywords: Cucumis melo var. momordica, genetic variability, snow melon, papoco melon.

\section{RESUMO}

Divergência genética em acessos de melão do grupo momordica

A divergência genética de genótipos de melão do grupo momordica foi estimada, coletados em cinco estados brasileiros, e determinada a contribuição relativa dos caracteres morfológicos avaliados para a variabilidade genética. Foi adotado o delineamento de blocos casualizados com quatro repetições. Nesse estudo, foram utilizados 19 acessos de melão do grupo momordica, dois acessos do grupo cantaloupensis e duas cultivares comerciais do grupo inodorus. Esses genótipos foram caracterizados por meio de 42 descritores morfológicos. Os dados foram submetidos aos métodos de agrupamento de Tocher e UPGMA a partir da matriz de dissimilaridade genética de Mahalanobis $\left(\mathrm{D}^{2}\right)$. Foi utilizado o critério de Singh, para identificar a contribuição relativa de cada caráter para a divergência genética. Obtiveram-se quatro grupos de similaridade em ambas as técnicas multivariadas utilizadas, havendo concordância entre os métodos hierárquicos UPGMA e de agrupamento de Tocher. Os caracteres, tamanho da cicatriz do pistilo, teor de sólidos solúveis, comprimento da semente, comprimento de fruto e comprimento do cotilédone contribuíram com aproximadamente 53,86\% para a divergência genética entre os genótipos.

Palavras-chaves: Cucumis melo var. momordica, variabilidade genética, melão de neve, melão papoco.

Received on March 30, 2016; accepted on November 14, 2017

$\mathrm{M}$ elon (Cucumis melo), belonging to Cucurbitaceae family, is one of the species presenting great genetic variability for several characters, mainly with respect to fruits. Due to this fact, some intraspecific classifications of $C$. melo have been suggested, over time, by Cogniaux \& Harms (1924), Pangalo (1933), Filov (1960), Whitaker \& Davis (1962), Grebenšcikov (1986), Munger \& Robinson (1991) and Pitrat et al. (2000) cited by Aragão (2011).

One of the most recent classification, and widely used in literature, proposed to divide the species into six botanical groups: cantaloupensis, inodorus, conomon, dudaim, flexuosus and momordica (Robinson \& DeckerWalters, 1997). Many of these groups are economically important in developed countries and they were based on their culinary attributes (Staub et al., 2000). We highlight that different botanic groups can be crossed among each other, without any incompatibility barriers (Aragão, 2011).

The botanical groups inodorus and cantaloupensis are considered the most important ones considering the commercial value, and in these groups we can also find the most commonly grown and widely marketed varieties in Brazil, yellow melon and piel de sapo melon (Aragão, 2011). The yellow melon is Brazil's most exported melon fruit, followed by orange flesh and piel de sapo, with 60, 15 and 9\% of exportations, respectively (Nunes et al., 2011).

On the other hand, in the national market, the local or native cultivars have been dividing space with the commercial 
cultivars in some areas of Brazil. These cultivars are adapted to several soil and climatic conditions (Torres Filho et al., 2009) and have been grown over time by family farmers, and can be used as parents in melon breeding programs.

The melons belonging to momordica group are known by different names in the countries where they are found. In tropical and subtropical regions of India, the melons are vulgarly known as "phut" or "snapmelon". In some Brazilian regions, they are known as papoco melon, meloite, snow melon and vitamin melon. Among the most striking characteristics is the rupture of the fruit when it reaches ripeness, low total soluble solid content, besides exhaling a soft aroma similar to melons of the cantaloupensis group. Because having a flavor of naturally tasteless pulp, they are consumed in natura with sugar, honey or other sweeteners, besides being used for the preparation of soft drinks, salads and pickles when ripe or cooked when immature (Valadares, 2014; Dhillon et al., 2007).

Accessions of momordica group melons with genetic resistance to several diseases were observed. Among these diseases can be related the ones caused by the fungus Fusarium oxysporium, Podosphaera xanthii, Myrothecium roridum (Nascimento et al., 2012), by the nematode Meloidogyne incognita, by PRSV virus (Papaya Ring Spot Virus) (Dhillon et al., 2007), and some pests like the leafminer Liriomyza trifolii and aphid Aphis gossypii (Fergany et al., 2011).

In order to use the genetic variability of Brazilian melon populations belonging to momordica group, some collections of traditional varieties in the main producer regions are necessary, as well as the characterization using morphological descriptors available in literature aiming to identify favorable characters and characters of interest for the breeding program of this vegetable.

The aim of this study was to estimate genetic divergence of melon genotypes of momordica group, collected in five Brazilian States, and determine the relative contributions of the evaluated morphological characters.

\section{MATERIAL AND METHODS}

The experiment was installed in the Department of Agronomy, at the Area of Phytotechnology at Universidade Federal Rural of Pernambuco, Campus Dois Irmãos, Recife, from April to July, 2013. The plants were conducted in hydroponic system in a greenhouse, arch type, $30 \mathrm{~m}$ length, $14 \mathrm{~m}$ width, 3 $\mathrm{m}$ ceiling height, closed laterally with $50 \%$ shading screen and covered with low-density polyethylene film, $150 \mu \mathrm{m}$.

The experimental design was randomized blocks, with 23 treatments, four replicates and two plants per experimental plot. The authors evaluated 19 accessions of melon belonging to momordica group collected in the States of Pernambuco, Bahia, Minas Gerais, Paraná and Rio Grande do Sul, two accessions of cantaloupensis group from Maranhão and two commercial cultivars of inodorus group (Table 1).
Sowing was performed in expanded polystyrene trays of 128 cells, containing pine bark-based substrate for vegetable. The seedlings were transplanted into 5 L-capacity pots using coconut powder as substrate, in a spacing of $0.60 \times 1.75$ $\mathrm{m}$, ten days after planting, after the first definitive leaf appeared.

The plants were staken vertically using plastic ribbons and wire at $1.30 \mathrm{~m}$ height and at the base of the plant. After the appearance of the fifth leaf, from the third leaf on, we eliminated the tertiary shoots up to the eighth leaf, conducting the plant with only one secondary stem. Both, the tertiary and secondary stems which appeared after the eighth leaf, were pruned after the second leaf.

The side screens of the greenhouse were lifted during the day in order to allow the entrance of pollinating agents. During fructification period, thinning was performed, letting just two fruits per plant in different tertiary stems in order to reduce the competition between the

Table 1. Accessionss of C. melo with identifications and origins. Recife, UFRPE, 2013.

\begin{tabular}{lcc}
\hline Accessions/cultivars & Botanical group & Origin \\
\hline A01 & momordica & São José do Egito-PE \\
A02 & momordica & Granito-PE \\
A03 & momordica & Triunfo-PE \\
A04 & momordica & Petrolina-PE \\
A05 & momordica & São Lourenço da Mata-PE \\
A06 & momordica & Ibimirim-PE \\
A07 & momordica & Lagoa de Itaenga-PE \\
A08 and A09 & momordica & Serra Talhada-PE \\
A10 and A11 & momordica & Floresta-PE \\
A12 & momordica & Arcoverde-PE \\
A13 & momordica & Buíque-PE \\
A14 & momordica & Belo Jardim-PE \\
A15 & momordica & Mocambinho-MG \\
A16 & momordica & Juazeiro-BA \\
A17 & momordica & Jeremoabo-BA \\
A18 & momordica & Santa Tereza do Oeste-PR \\
A19 & momordica & Nova Petrópolis-RS \\
A20 and A21 & cantalupensis & Chapadinha-MA \\
A22 & inodorus & - \\
A23 & inodorus & - \\
\hline
\end{tabular}

${ }^{1}$ Simple hybrid of the commercial cultivar Gold Mine from the commercial company Seminis; ${ }^{2}$ Simple hybrid of the commercial cultivar Mandacaru from the commercial company Clause Tézier. 


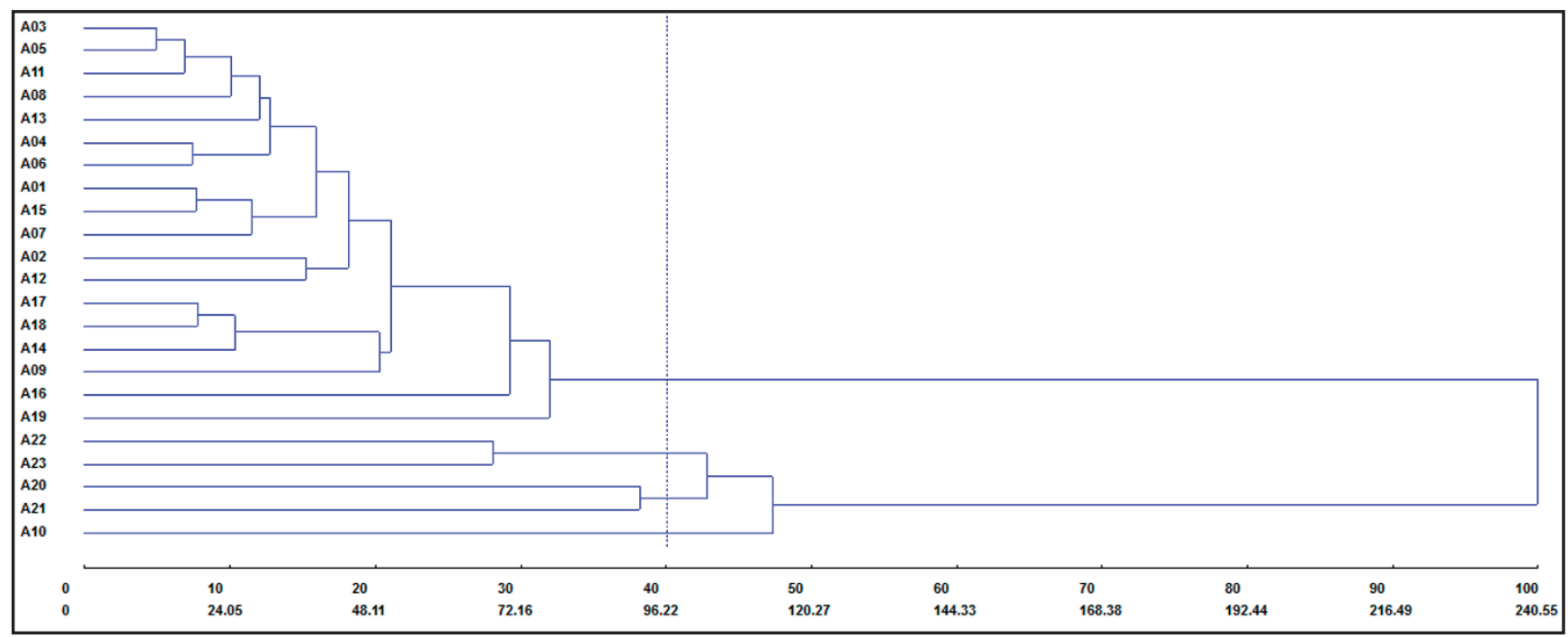

Figure 1. Dendrogram resulting from the analysis of 23 accessions of Cucumis melo, obtained using UPGMA grouping method, and Mahalanobis distance. Recife, UFRPE, 2013.

fruits, favoring their development and higher quality for harvest.

Mineral nutrition and need of water were supplied through balanced nutrient solution in each stage of the plant development through a drip irrigation system using an emitter flow rate of $2 \mathrm{~L}$ $\mathrm{h}^{-1}$, two to four times a day, according to the weather conditions and water absorption by the plants. The supply of nutrient solution was suspended with the start of the drainage at the bottom of the pots.

In order to verify the genetic variability of papoco melon genotypes, some morphological evaluations were made of the seeds, plants and fruits based on the list of minimum descriptors established for melon by SNPC (National Service for Plant Variety Protection) and recommended for tests of distinctiveness, homogeneity and stability, also called test DHE, MAPA (Ministry of agriculture, livestock and food supply) (MAPA, 2008).

After obtained all data, multivariate analyses through hierarchical grouping technique, based on UPGMA, using Mahalanobis generalized distance $\left(\mathrm{D}^{2}\right)$, using the dissimilarity measure (Cruz et al., 2012, 2014), were performed. The optimization was verified using Tocher method (Cruz et al., 2012, 2014). In order to verify the efficiency of the hierarchical grouping method, the authors estimated the cophenetic correlation coefficient (Sokal \& Rohlf, 1962). The criterion of Singh was used to identify the relative contribution of each character for genetic divergence (Cruz et al., 2012, 2014). Data analysis was performed using the computer software GENES (Cruz, 2013).

\section{RESULTS AND DISCUSSION}

Dissimilarity averages between each pair of the accessions obtained using Mahalanobis generalized distance $\left(\mathrm{D}^{2}\right)$ allowed forming four similarity groups (Figure 1). Group I was formed by $94.74 \%$ of the evaluated accessions, however only the accession A19 showed the background color of the peel, intensity of the background color of the peel, peel color hue, fruit base shape, fruit apex shape and placental color different from the characters observed in the other accessions of momordica group, with yellow color, dark intensity, orange toned, round-based shape, flat apex, and salmon-colored placenta (Table 2).

The second group took into consideration two cultivars belonging to inodorus group, Gold Mine and Mandacaru, which differed only in relation to the shape of the longitudinal, circular and middle elliptical section, respectively. The third group included the accessions A20 and A21 belonging to cantaloupensis group, which differed in relation to the placenta color, showing salmon and orange color, respectively (Table 2). The last group was formed only by the accession A10 which stood out in relation to the other accessions of momordica group, since it showed soluble solid content about $5 \%$ and did not show any cracks in fruits at maturity, white peel color and yellowish white flesh color, characters which are opposite to that observed in the other accessions of momordica group (Table 2). Fruit rupture in accessions of momordica group was observed in studies carried out previously by Valadares (2014), Torres Filho et al. (2009) and Dhillon et al. (2007).

The grouping of accessions using Tocher method showed to be similar to UPGMA method considering the groups formed among the most divergent accessions (Table 3 ). The similarity between the two used grouping techniques can be verified by the fact that the accessions of momordica group belonging to groups I, Tocher group, were the same as the groupings by UPGMA method. Agronomic characters different from this first group are expected for the accessions A22, A23 (Group II), A20, A21 (Group III), due to the fact that they formed isolated groups, and the accession A10 (Group IV) has formed an isolated group, similar to the one observed using UPGMA method; 
Table 2. Characterization of accessions and cultivars of melon from qualitative descriptors of the fruit. Recife, UFRPE, 2013.

\begin{tabular}{lllllllllllllllllllll}
\hline $\begin{array}{l}\text { Accessions/ } \\
\text { cultivars }\end{array}$ & VFR MCA & PDI & FSL & IFU & TCA & FBA & FAP & SUL & CSU & RSU CPO & CPL & AIN & AEX RFR FRU \\
\hline A01 & Méd & FDe & DFl & Obo & Cla & Esb & Arr & Arr & Aus & - & Aus & Br & Lar & Pr & Pr & Pro & Alt \\
A02 to A09 & Méd & FDe & DFl & Obo & Cla & Esb & Pon & Arr & Aus & - & Aus & Br & Lar & Pr & Pr & Pro & Alt \\
A10 & Méd & FDe & DFl & Obo & Cla & Esb & Arr & Arr & Aus & - & Aus & BAm & Lar & Pr & Pr & Aus & \\
A11 and A12 & Méd & FDe & DFl & Obo & Cla & Esb & Pon & Arr & Aus & - & Aus & Br & Lar & Pr & Pr & Pro & Alt \\
A13 & Méd & FDe & DFl & Obo & Esc & Am & Pon & Arr & Aus & - & Aus & Br & Lar & Pr & Pr & Pro & Alt \\
A14 to A18 & Méd & FDe & DFl & Obo & Cla & Esb & Pon & Arr & Aus & - & Aus & Br & Lar & Pr & Pr & Pro & Alt \\
A19 & Méd & FDe & DFl & Obo & Esc & Ala & Arr & Pla & Aus & - & Aus & Br & Sal & Pr & Pr & Pro & Alt \\
A20 & Esc & FDe & NCe & EAl & Esc & Ala & Pla & Pla & For & Bra & Aus & Lar & Sal & Pr & Pr & Aus & - \\
A21 & Esc & FDe & NCe & EAl & Esc & Ala & Pla & Pla & For & Bra & Aus & Lar & Lar & Pr & Pr & Aus & - \\
A22 & Cla & FDe & DPe & Cir & Esc & Am & Arr & Arr & Aus & - & Méd & BEs & Bra & Aus & Aus & Aus & - \\
A23 & Cla & FDe & DPe & EMe & Esc & Am & Arr & Arr & Aus & - & Méd & BEs & Bra & Aus & Aus & Aus & - \\
\hline
\end{tabular}

$\mathrm{VFR}=$ intensity of the green color of the young fruit peel $(\mathrm{Cla}=$ light; Méd= medium; Esc= dark); $\mathrm{MCA}=$ change from the color of the young fruit peel to the ripe fruit $(\mathrm{FDe}=$ at the end of fruit development); $\mathrm{PDI}=$ position of maximum diameter $(\mathrm{DFl}=$ toward the flower; $\mathrm{NCe}=$ in the center; $\mathrm{DPe}=$ toward the peduncle $) ; \mathrm{FSL}=$ shape of longitudinal section $(\mathrm{Obo}=$ obovate; $\mathrm{Cir}=$ round, $\mathrm{EAl}=$ wide elliptic; $\mathrm{EMe}=\mathrm{average}$ elliptic); IFU= intensity of the background color of the peel $(\mathrm{Cla}=$ light; $\mathrm{Esc}=$ dark $)$;CA= peel color hue $(\mathrm{Esb}=\mathrm{whitish}$; $\mathrm{Am}=\mathrm{yellowish}$; $\mathrm{Ala}=$ orange $) ; \mathrm{FBA}=$ base shape $(\mathrm{Pon}=$ pointed; $\mathrm{Arr}=$ rounded; $\mathrm{Pla}=$ flat $) ; \mathrm{FAP}=$ apex shape $(\mathrm{Arr}=$ rounded; $\mathrm{Pla}=\mathrm{flat}) ; \mathrm{SUL}=\mathrm{grooves}(\mathrm{Aus}=$ absent or very weakly expressed; For = strong); $\mathrm{CSU}=$ groove color $(\mathrm{Bra}=$ white); RSU $=$ surface roughness $($ Aus $=$ absent or very weak; Méd= medium); $\mathrm{CPO}=$ main color of the flesh $(\mathrm{Br}=$ white; $\mathrm{BAm}=$ yellowish white; $\mathrm{BEs}=$ greenish white; $\mathrm{Lar}=\mathrm{orange}) ; \mathrm{CPL}=\mathrm{placenta}$ color $(\mathrm{Lar}=$ orange; $\mathrm{Sal}=$ salmon, $\mathrm{Bra}=$ white $) ; \mathrm{AIN}=$ aroma inside the fruit $(\mathrm{Pr}=$ present; Aus $=$ absent $) ; \mathrm{AEX}=$ aroma outside of the fruit $(\mathrm{Pr}=$ present; Aus= absent $) ; \mathrm{RFR}=$ fruit rupture $(\mathrm{Pro}=\mathrm{deep} ; \mathrm{Aus}=\mathrm{absent}) ; \mathrm{FRU}=$ fruit rupture frequency $(\mathrm{Alt}=\mathrm{high})$.

Table 3. Grouping using Tocher method and the Mahalanobis distance, for the 23 accessions of C. melo. Recife, UFRPE, 2013.

\begin{tabular}{ll}
\hline Groups & Accessions \\
\hline I & $\mathrm{A} 19, \mathrm{~A} 16, \mathrm{~A} 09, \mathrm{~A} 14, \mathrm{~A} 18, \mathrm{~A} 17, \mathrm{~A} 12, \mathrm{~A} 02, \mathrm{~A} 07, \mathrm{~A} 15, \mathrm{~A} 01, \mathrm{~A} 06$, \\
& $\mathrm{A} 04, \mathrm{~A} 13, \mathrm{~A} 08, \mathrm{~A} 11, \mathrm{~A} 05$ and A03 \\
\hdashline $\mathrm{II}_{\mathrm{I}}$ & $\mathrm{A} 22, \mathrm{~A} 23$
\end{tabular}

this fact occurs due to a specific character or a set of these characters had allowed an isolated group of the accession A10, the only accession in momordica group, possibly the characters of pistil scar size and soluble solid content were the most determinant for the isolation of accession A10 (Table 4).

An agreement between multivariate and grouping technique is important for the genetic diversity study, since this evaluation makes it possible to recommend crossing between more divergent parents, in order to broaden the genetic base and, consequently, to increase variability (Abreu et al., 2004).The use of different grouping methods provides more efficient support for determination of divergence, since Tocher method discriminates each group and UPGMA discriminates each genotype, helping, with greater security, choose parents in breeding programs (Bertan et al., 2006).

The analysis of relative contribution of each character for genetic divergence expression using Singh method considers that the most important characters express greater variability. Thus, the authors verified that all the evaluated characters contributed to determine genetic divergence among the evaluated accessions, to a greater or lesser extent. Soluble solid content
(17.60\%), seed length $(13.41 \%)$, fruit length $(11.80 \%)$, cotyledon length $(11.05 \%)$ and pistil scar size $(9.41 \%)$, were the descriptors which contributed the most for divergence among the 23 evaluated accessions of $C$. melo, which explains $53.86 \%$ of total dissimilarity (Table 4). On the other hand, the character which contributed the least was fruit shape index $(0.31 \%)$, shown in Table 4.

In the genetic divergence study from Paiva (2002) using lines of melons belonging to cantaloupensis, inodorus and momordica groups, and by Rizzo \& Braz (2002) studying genetic divergence among five genotypes of net melon, soluble solid content was also one of the characters which most contributed to genetic variability.

According to Alves et al. (2003), evaluating the relative importance of the characters, it is interesting due to the possibility of discarding the characters which little contribute to discriminate the evaluated genotypes, reducing labor, time and cost spent on experiments.

Cophenetic correlation coefficient ( $\mathrm{r}$ ) was 0.89 showing that good adjustment 
Table 4. Relative contribution (S.j) of 22 quantitative descriptors for the genetic divergence among accessions, using Singh's method. Recife, UFRPE, 2013.

\begin{tabular}{lrr}
\hline Characteristic & \multicolumn{1}{c}{ S.j } & S.j $\mathbf{( \% )}$ \\
\hline DPEN & 255.426 & 1.043 \\
TCPI & 2305.021 & 9.419 \\
CFRU & 2887.636 & 11.800 \\
LFRU & 802.719 & 3.280 \\
IFOR & 88.832 & 0.363 \\
EPOL & 273.630 & 1.118 \\
TSSO & 4307.231 & 17.601 \\
MMFR & 905.294 & 3.699 \\
CSEM & 3282.439 & 13.414 \\
LSEM & 613.904 & 2.508 \\
RSEM & 295.180 & 1.206 \\
CCOT & 2704.718 & 11.053 \\
LCOT & 795.368 & 3.250 \\
RCOT & 861.740 & 3.521 \\
CPEC & 632.156 & 2.583 \\
CFOL & 605.498 & 2.474 \\
LFOL & 331.796 & 1.355 \\
RFOL & 352.413 & 1.440 \\
CLTE & 250.295 & 1.022 \\
FMAS & 322.122 & 1.316 \\
FFEM & 481.85 & 1.969 \\
MATU & & 4.556 \\
\hline Total & 114.919 & 100 \\
\hline PPEN-p & \\
\hline
\end{tabular}

DPEN= peduncle diameter; $\mathrm{TCPI}=$ pistil scar size; $\mathrm{CFRU}=$ fruit length; $\mathrm{LFRU}=$ fruit width; $\mathrm{IFOR}=$ fruit length/width ratio; $\mathrm{EPOL}=$ pulp thickness; $\mathrm{TSSO}=$ soluble solid content; $\mathrm{MMFR}=$ average fruit mass; $\mathrm{CSEM}=$ seed length; $\mathrm{LSEM}=$ seed width; $\mathrm{RSEM}=$ seed $\mathrm{C} / \mathrm{L}$ ratio; $\mathrm{CCOT}=$ cotyledon length, $\mathrm{LCOT}=$ cotyledon width, $\mathrm{RCOT}=$ cotyledon $\mathrm{C} / \mathrm{L}$ ratio; $\mathrm{CPEC}=$ petiole length; $\mathrm{CFOL}=$ leaf length, $\mathrm{LFOL}=$ leaf width, $\mathrm{RFOL}=$ leaf $\mathrm{C} / \mathrm{L}$ ratio; $\mathrm{CLTE}=$ terminal lobe length, FMAS= number of days for male flowering; FFEM= number of days for female flowering; MATU= number of days for maturation.

between graphical representation of distances and its original matrix could be noticed. The adjustment of cophenetic correlation coefficient is considered good when it shows values equal or superior to (r) 0.70 (Sokal \& Rohlf, 1962). Cophenetic correlation coefficient enables visual inferences (dendogram) and the higher its estimate, the lower the grouping distortion, presenting a good adjustment between the matrix and the formed dendrogram (Cruz et al., 2012).

Given the results, the authors verified an agreement between hierarchical UPGMA and Tocher grouping methods. The characters that permitted the visualization of genetic variability among 23 evaluated accessions, evaluated through four distinct groups, were soluble solid content, seed length, fruit length, cotyledon length and pistil scar size. These characters were the ones which most contributed to genetic divergence among the accessions. Due to this fact, the evaluated accessions may constitute a potential to be used in breeding programs, in order to obtain good materials for in natura consumption or for industrialization.

\section{ACKOWLEDGEMENTS}

This research is part of the MSc thesis of the first author, presented at UFRPE.

\section{REFERENCES}

ABREU, FB; LEAL, NR; RODRIGUES, R; AMARAL, JRAT; SILVA, DJH. 2004. Divergência genética entre acessos de feijãode-vagem de crescimento indeterminado. Horticultura Brasileira 22: 547-552.

ALVES, RM; GARCIA, AAF; CRUZ, AD; FIGUEIRA, A. 2003. Seleção de descritores botânico-agronômicos para caracterização de germoplasma de cupuaçuzeiro. Pesquisa Agropecuária Brasileira 38: 807-818.

ARAGÃO, FAS. 2011. Divergência genética de acessos e interação genótipo $x$ ambiente de famílias de meloeiro. Mossoró: UFERSA. 107p (Tese doutorado).

BERTAN, I; CARVALHO, FIF; OLIVEIRA, AC; VIEIRA, EA; HARTWIG, I; SILVA, JAG; SHIMIDT, DAM; VALÉRIO, IP; BUSATO, CC; RIBEIRO, G. 2006. Comparação de métodos de agrupamento na representação da distância morfológica entre genótipos de trigo. Revista Brasileira de Agrociência 12: 279-286.

CRUZ, CD; CARNEIRO, PCS; REGAZZI, AJ. 2014. Modelos biométricos aplicados ao melhoramento genético. $3^{\mathrm{a}}$ ed. Viçosa: UFV. $668 \mathrm{p}$.

CRUZ, CD; REGAZZI, AJ; CARNEIRO, PCS. 2012. Modelos biométricos aplicados ao melhoramento genético. $4^{\mathrm{a}}$ ed. Viçosa: UFV. $514 \mathrm{p}$.

CRUZ, CD. 2013. GENES - a software package for analysis in experimental statistics and quantitative genetics. Acta Scientiarum 35: 271-276.

DHILON, NPS; RANJANA, R; SINGH, K; EDUARDO, I; MONFORTE, AJ; PITRAT, M; DHILON, NL; SINGH, PP. 2007. Diversity among landraces of Indian snapmelon (Cucumis melo var. momordica). Genetics Resources Crop Evolution 54: 1267-1283.

FERGANY, M; KAUR, B; MONFORTE, AJ; PITRAT, M; RYS, C; LECOQ, H; DHILLON, NPS; DHALIWAL, SS. 2011. Variation in melon (Cucumis melo) landraces adapted to the humid tropic of southern India. Genetic Resources and Crop Evolution 58: 225-243.

MAPA - Ministério da Agricultura, Pecuária e Abastecimento. 2008. Formulários para proteção de cultivares. Espécies em regime de proteção: instruções de DHE e tabela de descritores mínimos. Olerícolas, Melão (Cucumis melo L.). Disponível em: http:// www.agricultura.gov.br/ Accessed June 28, 2013.

NASCIMENTO, IJB; NUNES, GHS; SALES JÚNIOR, R; SILVA, KJP; GUIMARÃES, IM; MICHEREFF, SJ. 2012. Reaction of melon accessions to crater rot and resistance inheritance. Horticultura Brasileira 30: 459-465.

NUNES, GHS; FILHO, JHC; SILVA, DJH; CARNEIRO, PCS; DANTAS, MSM. 2011. Divergência genética entre linhagens de melão pele de sapo. Ciência Agronômica 42: 765-773.

PAIVA, WO. 2002. Divergência genética entre linhagens de melão e a heterose de seus híbridos. Horticultura Brasileira 20: 34-37. 
RIZZO, AAN; BRAZ, LT. 2002. Divergência genética entre cinco genótipos de melão rendilhado. Horticultura Brasileira 20: 171-173.

ROBINSON, RW; DECKER-WALTERS, DS. 1997. Cucurbits. New York: CAB International. 226p.

SOKAL, RR; ROHLF, FJ. 1962. The comparison of dendrograms by objective methods. Taxonomy 11: 33-40.

STAUB, JEY; DANIN-POLEG, G; FAZIO, T; HOREJSI, N; REIS, N; KATZIR, N. 2000. Comparison analysis of cultivated melon groups (Cucumis melo L.) using random amplified polymorphic DNA and simple sequence repeat markers. Euphytica 115: 225-241.
TORRES FILHO, J; NUNES, GHS ; VASCONCELOS, JJC. 2009. Caracterização morfológica de acessos de meloeiro coletados no nordeste brasileiro. Caatinga 22: 174-181.

VALADARES, RN. 2014. Caracterização morfológica e estimativas de parâmetros genéticos em melão do grupo momordica. Recife: UFRPE. 93p (Dissertação mestrado). 
MAMBRÍ, APS; ANDRIOLO, JL; MANFRON, MP; PINHEIRO, SMG; CARDOSO, FL; NEVES, MG. 2018. Yield and composition of lavender essential oil grown in substrate. Horticultura Brasileira 36: 259-264. DOI: http://dx.doi.org/10.1590/S0102-053620180219

\title{
Yield and composition of lavender essential oil grown in substrate
}

\author{
Ana PS Mambrí; Jerônimo L Andriolo; Melânia P Manfron; Suany MG Pinheiro; Francieli L Cardoso; \\ Myriam G Neves
}

Universidade Federal de Santa Maria (UFSM), Santa Maria-RS, Brazil; ana.mambri@gmail.com; jeronimoandriolo@gmail.com; melaniapalermo@gmail.com; suanygp@hotmail.com; agronomyriam@hotmail.com; franci-lc@hotmail.com

\begin{abstract}
The objective of this research was to evaluate the effect of successive harvesting times and shading on the production of biomass, yield and phytochemical composition of essential oil in leaves and inflorescences of soilless grown Lavandula dentata. Plants were grown in pots filled with sand, inside a polyethylene greenhouse, in a closed system at UFSM. Plants were harvested at 150, 213 and 320 days after planting date (DAP) in winter, spring and summer, respectively. At $150 \mathrm{DAP}$, a 50\% shading screen was installed. The experimental design was a randomized $3 \times 2$ factorial in subdivided plots with 36 plants per subplot. Fresh (FM) and dry mass (DM), yield and chemical composition of essential oil in leaves and inflorescences were determined after each harvest date. The essential oil was extracted, using $70 \mathrm{~g}$ fresh mass of leaves and of inflorescences, respectively. Identification and quantification of compounds in the essential oil were determined by gas chromatography/mass spectrometry (GC/MS). The FM of inflorescences was higher on plants harvested 213 DAP grown without shading while of leaves it was higher on plants harvested 320 DAP grown without shading. The yield of the essential oil was higher in the leaves of plants harvested 320 DAP grown without shading. Thirty-one compounds were identified and quantified, being the major ones 1.8 cineol, camphor and linalool, without significant difference among treatments. Three consecutive harvests can be made in August (150 DAP), October (213 DAP) and February (320 DAP) without replacing plants.
\end{abstract}

Keywords: Lavandula dentata, aromatic plant, phytomass, solar radiation.

\section{RESUMO}

Rendimento e composição do óleo essencial de lavanda cultivada em substrato

Avaliou-se o efeito de sucessivas épocas de colheita e do sombreamento na produção de fitomassa, rendimento e composição fitoquímica do óleo essencial de folhas e inflorescências de Lavandula dentata em cultivo fora do solo. As plantas foram cultivadas em vasos preenchidos com areia, no interior de um abrigo de polietileno, em sistema fechado na UFSM. Foram realizadas três coletas sucessivas aos 150, 213 e 320 dias após o plantio (DAP), no inverno, primavera e verão, respectivamente. Aos 150 dias após o plantio, foi instalada tela com $50 \%$ de sombreamento. O delineamento experimental foi fatorial $3 \times 2$ casualizado em parcelas subdivididas com 36 plantas por subparcela. A massa fresca (MF) e seca (MS), o rendimento e a composição química do óleo essencial de folhas e inflorescências foram determinados em cada coleta. O óleo essencial foi extraído utilizando $70 \mathrm{~g}$ de massa fresca de folhas e de inflorescências, respectivamente. A identificação e a quantificação dos compostos no óleo essencial foram determinadas por cromatografia gasosa/espectrometria de massas (GC/MS). A MF das inflorescências foi mais elevada na colheita, aos 213 DAP sem sombreamento, enquanto a MF de folhas foi mais elevada na colheita de 320 DAP sem sombreamento. O rendimento do óleo essencial foi mais elevado nas folhas, aos 320 DAP sem sombreamento. Foram identificados e quantificados 31 compostos, sendo majoritários 1,8 cineol, cânfora e linalol sem diferença significativa entre os tratamentos. Realizando o plantio em substrato no início de março podem ser feitas três colheitas sucessivas em agosto (150 DAP), outubro (213 DAP) e fevereiro (320 DAP) sem substituição das plantas.

Palavras-chave: Lavandula dentata, planta aromática, fitomassa, radiação solar.

\section{Received on July 15, 2016; accepted on January 3, 2017}

$\mathrm{P}$ lants with aromatic and medicinal properties, such as lavenders, have been attracting growing interest in the national market. Their bioactive secondary compounds are used to obtain products with perfumery or therapeutic action. Lavandula dentata, popularly known as French lavender are plants grown commercially for the extraction of essential oil and also employed as ornamentals and for honey production. Lavender has a wide adaptation in diverse climatic and soil conditions, being found in several countries in Europe, the Middle East, Asia and North Africa where it is used as source of raw material in the pharmaceutical, food, cosmetics, aromas and agroindustry (Biasi \& Deschamps, 2009). In Brazil, through technology and innovation for cultivation, it is possible to achieve significant productivity of this species (Silva, 2015).

Several compounds were cited as major components in lavender essential oil in plants grown in Algeria, Saudi Arabia, Spain, Morocco and Turkey: 1,8 cineole, camphor, borneol, fenchol, $\alpha$-pinene, $\beta$-pinene, trans-pinocarol and linalool (Bousmaha et al., 2005). 
Among these, some have antibacterial and antifungal properties (Aly et al., 2013), antioxidants and citotoxicity (Imelouane et al., 2010; Abdel-Hady et al., 2014). The composition and the relative proportion of the individual components constituting the essential oils are not constant, may vary according to the harvest times, the development stage of the plant and the different part of the plant (Bousmaha et al., 2005). According to Zheljazkov et al. (2013), the chemotype of the plant changes according to interactions with the environment such as temperature and solar radiation.

Lavender for essential oil production, in Brazil and other countries, is cultivated mainly in the field, with up to two annual harvests, when there is regrowth, usually made at maximum vegetative plant growth and/or full flowering (McNaughton, 2006). In southern Brazil, the growth and development of plants in conventional cultivation in soil in the winter months suffer negative effects of low temperatures and high rainfall (Alvares et al., 2014). To minimize these effects, the cultivation off-soil and in greenhouse is the alternative that allows the management of environmental conditions such as temperature and solar radiation intensity, as well as the availability of water and nutrients. The greenhouse also allows a better planning of production throughout the year. From the industrial point of view, several harvests of aromatic plants throughout the year are favorable for commercial production of essential oils.

The intensity of solar radiation can affect the growth, yield and composition of lavender essential oils (Zheljazkov et al., 2013). Solar radiation varies naturally throughout the seasons. In the central region of the State of Rio Grande do Sul, global solar radiation intensity is close to $8.4 \mathrm{MJ} \mathrm{m}^{-2}$ day $^{-1}$ in the winter months and can reach values close to $40 \mathrm{MJ} \mathrm{m}^{-2}$ day $^{-1}$ in summer (Alvares et al., 2014). The intensity in winter is in the trophic limit that has been indicated for the summer growing vegetables (FAO, 2013) while that in summer can reduce growth and affect plant physiology because it mainly alters the water potential of the plant. Publications show that the growth of lemon balm (Melissa officinalis) cultivated in soil was favored by shading (Brant et al., 2009) and reduced in basil plants (Ocimum basilicum) grown in pots in the greenhouse (Chang et al., 2008). In both species, shading affected the composition of the oil. No results were found in the literature about the growth and yield of lavender oil at different planting periods through the year nor the effect of solar radiation intensity over these variables.

The objective of this research was to evaluate the effect of successive cropping periods and two intensities of solar radiation in the production of biomass, yield and phytochemical composition of the essential oil of leaves and flowers of Lavandula dentata grown on substrate.

\section{MATERIAL AND METHODS}

The experiment was conducted in a polyethylene greenhouse in the experimental area of Plant Science Department of Federal University of Santa Maria (UFSM) from March 8, 2014 to February 6, 2015. The climate of the region is $\mathrm{Cfa}$, subtropical humid with no defined dry season (Alvares et al., 2014). The global solar radiation and the daily air temperature inside greenhouse were measured by Electronic Recorder (RHT10, Humidity and temperature USB datalogger ${ }^{\circledR}$ and Daqpro 5300 brand Fourier ${ }^{\circledR}$ ). The average daily temperatures were $18.2^{\circ} \mathrm{C}, 19.8^{\circ} \mathrm{C}$ and $25^{\circ} \mathrm{C}$ from planting date until harvest on each planting period: August (T1150DAP), October (T2-213DAP) and February (T3-320 DAP), respectively. The mean solar radiation was $8.84,10.41$ and $17.49 \mathrm{MJ} \mathrm{m}^{-2}$ respectively, in the same periods. For plants, growing under shading conditions, in the $\mathrm{T} 2$ and $\mathrm{T} 3$ seasons, the average temperatures were $21.1^{\circ} \mathrm{C}$ and $27.1^{\circ} \mathrm{C}$ and solar radiation 5.20 and $8.74 \mathrm{MJ} \mathrm{m}^{-2}$, respectively.

The material used for plant cultivation was composed of benches with $0.8 \mathrm{~m}$ height, made up by fiber cement tiles with $3.95 \mathrm{~m}$ in length and $1 \mathrm{~m}$ in width, supported with slope of $1 \%$ on a masonry structure. Tiles were coated with clear low density polyethylene film $(100 \mu \mathrm{m})$. Gullies, $6 \mathrm{~cm}$ high and $18 \mathrm{~cm}$ apart, were filled with medium-sized basaltic stone used in civil construction, with a particle size between 15 and $20 \mathrm{~mm}$. Polypropylene pots (3 liter capacity) were filled with sand particles $\left(>3 \mathrm{~mm}, 1.6 \mathrm{kh} \mathrm{dm}^{-3}\right)$ with water retention capacity of 238 $\mathrm{mL} \mathrm{dm}{ }^{-3}$. These pots were allocated above the gravel, arranged on benches in three rows, $35 \times 30 \mathrm{~cm}$ between rows and vessels in the row, totaling 36 pots per bench, one plant per pot.

Seedlings with a mean height of 15 $\mathrm{cm}$ were purchased locally and planted in pots at a density of nine plants per square meter. The nutrient solution was used for the soil-free cultivation of rosemary, with the following ionic composition, in mmol L-19 9.17 of $\mathrm{NO}_{3}^{-}$; $1.36 \mathrm{NH}_{4}^{+} ; 1.0 \mathrm{H}_{2} \mathrm{PO}_{4}^{-} ; 4.0 \mathrm{~K}^{+} ; 4.46 \mathrm{Ca}^{+2}$; $2.0 \mathrm{Mg}^{+2}$ and 2.0 of $\mathrm{SO}_{4}^{-2}$. Micronutrients were supplied at concentrations of, in $\mathrm{mg} \mathrm{L}{ }^{-1}, 0.03$ of Mo; $0.26 \mathrm{~B}$; $0.06 \mathrm{Cu}$; $0.50 \mathrm{Mn} ; 0.22$ of $\mathrm{Zn}$ and $1.0 \mathrm{mg} \mathrm{L}^{-1}$ of $\mathrm{Fe}$ in the chelated form (Frescura, 2014). Macronutrients were supplied through fertilizers potassium nitrate, monobasic ammonium phosphate, calcium nitrateCalcinit $^{\circledR}$ and magnesium sulfate. The electrical conductivity of this nutrient solution was $1.0 \mathrm{dS} \mathrm{m}^{-1}$ and the $\mathrm{pH}$ was 6,0 .

The nutrient solution was supplied through drip tapes connected to a pump submerged inside the reservoir, activated by a time programmer. For each row of vessels, a drip tape was distributed, with one dripper per vessel with $1.8 \mathrm{~L} \mathrm{~h}^{-1}$. A drainage coefficient of $30 \%$ was used in each fertirrigation and the drained solution was collected and returned to the storage tank, in a closed system. Up to eight 15 -min daily fertirrigations were estimated, taking into account maximum incident solar radiation, maximum potential transpiration of vegetables per unit foliar area (FAO, 2013) and the crop development stage, in order to maintain volume of water available in the substrate always close to that in the maximum water holding capacity.

The electrical conductivity was measured every two days and corrected whenever a variation of $10 \%$ was verified in relation to the initial value $(1.0 \mathrm{dS}$ 
$\mathrm{m}^{-1}$ ), by adding water or aliquots of new nutrient solution, with concentration and volume adjusted to reach the initial value. The $\mathrm{pH}$ was maintained between 5.5 and 6.5 tolerating a deviation of 0.2 units by adding $\mathrm{NaOH}$ or $\mathrm{H}_{2} \mathrm{SO}_{4}$ in the $1 \mathrm{~N}$ concentration as needed. The nutrient solution inside reservoirs was completed whenever the volume reached $50 \%$ of the original volume.

Three harvest periods were compared in winter (T1-150 DAP), spring (T2-213 DAP) and late summer (T3-320 DAP), respectively. Plants were harvested on each period at senescence of the basal leaves. On the first harvest period (T1), all plants of the experimental area were harvested at 150DAP. All secondary stems were pruned in the third stem from the beginning of the stem. Immediately after this first harvest, shading was applied through a black polypropylene screen with $50 \%$ reduction of the global solar radiation, installed at 1.50 meters above the top of plants in 50\% of the internal area of the greenhouse, remaining until the end of experiment. Shaded and no-shaded plants were left to regrow after each harvest. The $\mathrm{T} 2$ and $\mathrm{T} 3$ treatments were harvested at 213 and 320 DAP respectively, according to the same criterion adopted for the first harvest.

The experimental design was randomized plots subdivided in a $3 \times 2$ factorial scheme, the harvest periods $(150,213$ and 320 DAP) in plots and the intensity of solar radiation (without and with shading) in subplots. Each plot consisted of a bench with 36 plants, with four replications. Growth determinations were made on ten plants drawn in the rows, excluding borders.

In each crop the inflorescences were manually separated from leaves and the fresh mass of inflorescences (MFI) and leaves (MFF) were evaluated. After harvest, inflorescence and leaves were dried in a forced circulation oven at $60^{\circ} \mathrm{C}$ until constant mass, obtaining the dry mass of inflorescence (MSI) and leaves (MSF). The fresh mass of the remaining plants in each plot was used to extract the essential oils in the laboratory.

For the extraction of the essential oil, the collected leaves and inflorescences were stored in a freezer at $4 \pm 0.1^{\circ} \mathrm{C}$. Leaves and inflorescences $(70 \mathrm{~g})$ were crushed and deposited in the distillation flask, adding $500 \mathrm{~mL}$ of water and hydrodistilled in Clevenger type graduated apparatus during three hours. The essential oil was separated from the water and dried over anhydrous sodium sulfate and stored at $-4^{\circ} \mathrm{C}$. Analyzes were performed with four replicates.

The essential oil content (\%) was calculated from a ratio between the mass of essential oil and the sample biomass (oil mass/sample mass), while the yield of the essential oil $(\mathrm{g})$ was calculated from the ratio between the mass of oil and the fresh mass of leaves and flowers of the plant (fresh mass x mass oil)/ sample mass $\}$.

Composition of oil was determined by gas chromatography (GC) connected to a flame ionization detector (FID) in a system Agilent Technologies $6890 \mathrm{~N}$ GC-FID ${ }^{\circledR}$, equipped with capillary column HP $5 \mathrm{MS}$ ( $30 \mathrm{~m} \times 0.25 \mathrm{~mm}$, and $0.25 \mathrm{~mm}$ ). Helium was used as the entrainment gas at a flow rate of $1.3 \mathrm{~mL} /$ $\mathrm{min}$. The thermal programmer was 50 $300^{\circ} \mathrm{C}$ at a rate of $5^{\circ} \mathrm{C} / \mathrm{min}$. Duplicates of samples were processed in the same manner. Relative concentrations of the components were calculated based on GC peak areas without use of correction factors. The volume of oil injection was $1 \mu \mathrm{L}$.

GC-MS analyzes were performed on an Agilent Technologies system AutoSystem XL GC-MS operating in mode $\mathrm{EI}$ at $70 \mathrm{eV}$, equipped with a split injector $\left(250^{\circ} \mathrm{C}\right)$. The transfer line temperature was $280^{\circ} \mathrm{C}$. Helium was used at a flow of $\left(1.5 \mathrm{~mL} \mathrm{~min}^{-1}\right)$ equipped with HP 5MS capillary columns $(30 \mathrm{mx}$ $0.25 \mathrm{~mm} ; 0.25 \mathrm{~mm}$ film thickness) and an HP innowax (30 m x $0.32 \mathrm{~mm}$; 0.50 $\mathrm{mm}$ of film thickness). The temperature program was the same as that used for $\mathrm{GC}$ analysis. The volume injected was $1 \mu \mathrm{L}$ of the essential oils. The essential oil components were identified on the basis of the retention index (IR), with data of mass spectra and IR of literature (Adams, 1995).

Data were submitted to analysis of variance and significance of differences between the means determined by the test of Tukey, $5 \%$ probability, using the program SISVAR.

\section{RESULTS AND DISCUSSION}

There was a significant interaction between the three harvesting periods and shading for the evaluated fresh mass (MFI) and dry mass (MSI) characteristics of inflorescences (Table 1). The highest fresh mass means of inflorescences were observed in the harvest done in August before shading. $50 \%$ shading reduced the inflorescence yield by $37 \%$ in the harvest made at 213 DAP and $83 \%$ at 320 DAP.

For fresh leaf mass a significant effect was found among periods, but no significant effect of shading. However, mean dry mass of leaves showed a significant difference in shading and harvest periods. While the fresh leaf mass at 213 DAP and 320 DAP was similar in the no-shaded and shaded plants, dry mass of shaded plants was $36 \%$ and $38 \%$ lower at 213 DAP and 320 DAP, respectively. These results differ from those obtained by Brant $e t$ al. (2009) testing Melissa officinalis, using black mesh with 50\% reduction in solar radiation; they verified that growth was favored in full sun cultivation. However, similar effect was described by Gomes et al. (2009) studying Lippia citriodora with fresh and dry mass reduction by shading of $30 \%, 50 \%$ and $75 \%$. These differences may be associated to the availability of water, since in the soilless cultivation fertigation was adjusted in order to fully meet the diurnal water needs of plants.

The biomass production obtained in this study was superior compared to cultivation data in different regions of Brazil. In Uberlândia, Minas Gerais, the maximum biomass of leaves was $61 \mathrm{~g}$ plant $^{-1}$ in protected cultivation (Silva, 2015), while in the present experiment it reached a total of $910.4 \mathrm{~g} \mathrm{plant}^{-1}$ (Table 1). In the Curitiba region, inflorescences production was $9.08 \mathrm{~g} \mathrm{plant}^{-1}$ in field crop (Masetto, 2009), while in the present research we obtained 42.73 g plant ${ }^{-1}$. These differences can be attributed to the cultivation outside soil, to the harvesting period and to the 
Table 1. Fresh and dry mass $\left(\mathrm{g} \mathrm{plant}^{-1}\right)$ of inflorescences and leaves of Lavandula dentata in three harvest periods with and without shading. Santa Maria, UFSM, 2014.

\begin{tabular}{|c|c|c|c|c|}
\hline \multirow{4}{*}{ Periods (DAP) } & \multicolumn{4}{|c|}{ Inflorescences } \\
\hline & \multicolumn{2}{|c|}{ Fresh mass (g plant $\left.{ }^{-1}\right)$} & \multicolumn{2}{|c|}{ Dry mass (g plant $\left.{ }^{1}\right)$} \\
\hline & \multicolumn{4}{|c|}{ Shading } \\
\hline & $0 \%$ & $50 \%$ & $0 \%$ & $50 \%$ \\
\hline 150 & $33.88 \mathrm{~B}$ & & $7.95 \mathrm{~B}$ & \\
\hline 213 & $89.56 \mathrm{Aa}$ & $56.47 \mathrm{Ab}$ & $29.74 \mathrm{Aa}$ & $0.57 \mathrm{Ab}$ \\
\hline \multirow[t]{2}{*}{320} & $14.29 \mathrm{Ca}$ & $2.39 \mathrm{Bb}$ & $5.04 \mathrm{Ca}$ & $0.63 \mathrm{Ab}$ \\
\hline & \multicolumn{4}{|c|}{ Leaves } \\
\hline 150 & $276.43 \mathrm{~B}$ & & $49.10 \mathrm{C}$ & \\
\hline 213 & $238.66 \mathrm{Ba}$ & $239.27 \mathrm{Ba}$ & $70.30 \mathrm{Ba}$ & $44.80 \mathrm{Bb}$ \\
\hline 320 & 395.31 Aa & $334.34 \mathrm{Aa}$ & $121.30 \mathrm{Aa}$ & $75.40 \mathrm{Ab}$ \\
\hline
\end{tabular}

Means followed by the same uppercase and lowercase letters in columns and lines respectively, do not differ significantly from each other, Tukey, $\mathrm{p}<0.05$ ). $\mathrm{DAP}=$ Days after planting.

Table 2. Oil yield $\left(\mathrm{g}_{\text {plant }}{ }^{-1}\right)$ of leaves and inflorescences of Lavandula dentata in three harvest periods with and without shading. Santa Maria, UFSM, 2014.

\begin{tabular}{lcccc}
\hline & \multicolumn{5}{c}{ Yield $\left(\right.$ g plant $\left.^{-1}\right)$} \\
\cline { 2 - 5 } Periods (DAP) & \multicolumn{4}{c}{ Inflorescences } \\
\cline { 2 - 5 } & \multicolumn{5}{c}{ Shading } \\
\cline { 2 - 5 } & $\mathbf{0 \%}$ & $\mathbf{5 0 \%}$ & $\mathbf{0 \%}$ & $\mathbf{5 0 \%}$ \\
\hline 150 & $0.38 \mathrm{~A}$ & - & $0.52 \mathrm{C}$ & - \\
213 & $0.60 \mathrm{Aa}$ & $0.18 \mathrm{Ab}$ & $1.14 \mathrm{Ba}$ & $0.61 \mathrm{Bb}$ \\
320 & $0.15 \mathrm{Aa}$ & $0.01 \mathrm{Bb}$ & $2.40 \mathrm{Aa}$ & $1.57 \mathrm{Ab}$ \\
\hline
\end{tabular}

Means followed by same uppercase and lowercase letters in columns and lines respectively, do not differ significantly from each other, Tukey, $\mathrm{p}<0.05$ ).

harvesting of several harvests during the year.

The essential oil yield of the fresh plant parts including leaves and inflorescences, varied depending on the harvesting periods and shading (Table 2). The leaves presented higher yields than inflorescences, both in the no-shaded and shaded condition. These results differ from those found by Touati et al. (2011) in Tunisia, with the same species and stage of development, where the yield of inflorescences was $32.4 \%$ higher than that of leaves. This difference indicates that plants of the same species, grown in different regions may present different results in the accumulation of aromatic compounds.

The yield of leaf essential oil was higher in the harvested crop at 320 days after planting $\left(2.4 \mathrm{~g} \mathrm{plant}^{-1}\right)$ followed by 213 DAP $\left(1.14 \mathrm{~g} \mathrm{plant}^{-1}\right)$ and 150 DAP $\left(0.52 \mathrm{~g} \mathrm{plant}^{-1}\right)$. Shading reduced the oil yield by $46.5 \%$ and $31.6 \%$ in the periods 213 DAP (in spring) and 320 DAP (summer), respectively. Results from literature on the effect of shading on the production of essential oil showed that each species reacts differently. Reduced levels of solar radiation increase essential oil yield in basil plants (Ocimum gratissimum) (AdeAdemilua et al., 2013) and pariparoba (Pothomorphe umbellate) (Mattana et al., 2010) while decrease in peppermint (Mentha arvensis) (Chagas et al., 2013) and herb-copaiba (Otacanthus azureus) (Serudo et al., 2013). The results of this work indicate that Lavandula dentata can be included in the second group.

The highest flower yield was obtained at 213 DAP (spring). At 320 DAP (summer) there was a $25 \%$ reduction in essential oil yield. This reduction is attributed to the lower number of inflorescences at that time as well as to a higher proportion at the senescence stage at harvest time (data not shown). The highest content of $L$. dentata oil in inflorescences at the bud stage has been demonstrated in literature (Masetto et al., 2011). Effect of temperature and stage of development of Lavandula angustifolia inflorescences on oil yield was also observed by Hassiotis et al. (2014). In addition to this quantitative variation, the results also showed a qualitative variation between the essential oils of the two parts of the evaluated plant. These differences may be adaptive responses to ecological requirements. The results indicated that temperature and solar radiation increase the accumulation of volatile compounds. The same was found in research done with Lippia alba (Barros et al., 2009) and Salvia officinalis (Verma et al., 2015) where results showed that the harvest period during the year affected yield and quality of essential oil.

In GC-MS chromatographic analyzes all 31 constituents were identified representing $96-95 \%$ of the total essential oil in inflorescences and plant leaves (Table 3). In leaves the major constituents were 1,8 (38.57 to $41.09 \%$ ), linalool (10.56\% to $15.62 \%)$, camphor $(9.32 \%$ to $10.43 \%)$ and sabinene $(3.91 \%$ to $5.61 \%$ ). In inflorescences, the main constituents were 1,8 cineol $(32.48 \%$ to $40.65 \%)$, camphor $(18.32 \%$ to $25.14 \%)$, linalool $(7.22 \%$ to $11.59 \%)$ and fenchone $(5.72 \%)$. The contents of the constituents found in this work differ from those found in literature, which also vary among $L$. dentata plant-producing regions. In Algeria, the major compounds were 1,8-cineol, $\beta$-pinene, trans-pinocarveol and linalool (Bousmaha et al., 2005). In Morocco, the relative concentrations of betapinene, mirthenol and alpha-pinene were higher (Imelouane et al., 2010), while in Egypt other major constituents were found, as menta-1,5-dien-8-ol, caryophyllene, guiaol (Abdel-Hady et al., 2014). In this work some of these compounds are present in small amounts and others have not been found. These differences probably reflect the differentiated physiological responses of plants to conditions in the environment where they were grown, resulting in variability in phytochemical content.

There was variation in the 
Table 3. Chemical composition of the volatile oil of Lavandula dentata in three harvest periods (DAP) with and without shading. Santa Maria, UFSM, 2014.

\begin{tabular}{|c|c|c|c|c|c|c|c|c|c|c|c|}
\hline \multirow{3}{*}{ Constituent } & \multirow{3}{*}{$\mathbf{R I}^{\mathbf{a}}$} & \multicolumn{5}{|c|}{ Inflorescences } & \multicolumn{5}{|c|}{ Leaves } \\
\hline & & \multirow{2}{*}{150} & \multicolumn{2}{|c|}{213} & \multicolumn{2}{|c|}{320} & \multirow{2}{*}{150} & \multicolumn{2}{|c|}{213} & \multicolumn{2}{|c|}{320} \\
\hline & & & $0 \%$ & $50 \%$ & $0 \%$ & $50 \%$ & & $0 \%$ & $50 \%$ & $0 \%$ & $50 \%$ \\
\hline$\alpha$-tujone & 930 & 0.15 & 0.09 & 0.24 & 0.18 & 0.21 & 0.23 & - & - & 0.09 & 0.11 \\
\hline$\alpha$-pinene & 939 & 3.07 & 3.01 & 2.98 & 3.25 & 3.19 & 2.98 & 3.49 & 3.51 & 2.78 & 2.81 \\
\hline camphene & 953 & 1.26 & 1.13 & 1.37 & 0.98 & 1.07 & 0.15 & 0.16 & 0.24 & 0.14 & 0.32 \\
\hline sabinene & 976 & 4.09 & 3.75 & 3.91 & 4.17 & 4.25 & 5.37 & 3.94 & 5.61 & 4.35 & 3.91 \\
\hline$\beta$-pinene & 980 & 0.85 & 0.82 & 0.89 & 0.79 & 0.80 & 0.54 & 0.29 & 0.53 & 0.18 & 0.25 \\
\hline mircene & 991 & 0.13 & - & 0.07 & 0.10 & 0.19 & 1.09 & 1.03 & 1.48 & 0.75 & 0.86 \\
\hline limonene & 1031 & 1.45 & 1.39 & 1.62 & 1.35 & 1.58 & 0.12 & 0.10 & 0.17 & 1.48 & 1.93 \\
\hline 1,8-cineole & 1033 & 37.64 & 35.01 & 40.65 & 32.48 & 36.27 & 41.09 & 38.57 & 40 & 39 & 40.20 \\
\hline$\gamma$-terpinene & 1062 & 1.03 & 0.98 & 1.01 & 1.04 & 1.11 & 0.41 & 0.39 & 0.47 & 0.84 & 0.96 \\
\hline $\begin{array}{l}\text { cis sabinene } \\
\text { hydrate }\end{array}$ & 1068 & 0.85 & 0.79 & 0.56 & 0.63 & 0.78 & 0.07 & 0.11 & 0.15 & - & 0.09 \\
\hline $\begin{array}{l}\text { cis-linalool } \\
\text { oxide }\end{array}$ & 1074 & - & 0.08 & 0.13 & 0.09 & 0.12 & - & - & - & 0.16 & 0.27 \\
\hline fenchone & 1087 & 5.71 & 5.69 & 5.78 & 5.71 & 5.74 & 3.09 & 3.12 & 3.78 & 4.13 & 4.46 \\
\hline terpinolene & 1088 & 0.49 & 0.23 & 0.48 & 0.17 & 0.19 & 1.58 & 1.38 & 1.49 & 1.61 & 1.73 \\
\hline linalool & 1098 & 10.05 & 8.17 & 11.59 & 10.91 & 7.22 & 15.04 & 14.97 & 15.60 & 10.50 & 13.20 \\
\hline fenchol & 1112 & 2.39 & 2.12 & 3.28 & 2.46 & 3.04 & 2.76 & 3.01 & 3.10 & 1.89 & 2.14 \\
\hline canphor & 1143 & 18.32 & 18.95 & 25.14 & 18.58 & 21.73 & 9.86 & 9.32 & 10.40 & 10.10 & 10.30 \\
\hline borneol & 1165 & 0.62 & 0.61 & 0.78 & 0.31 & 0.92 & 0.19 & - & - & 0.07 & 0.12 \\
\hline lavandulol & 1167 & 0.07 & 0.13 & 0.25 & 0.69 & 0.71 & - & 0.41 & 0.58 & - & 0.16 \\
\hline 4-terpineol & 1177 & 1.24 & 1.05 & 1.18 & 1.50 & 1.09 & 3.87 & 2.93 & 3.09 & 2.46 & 2.67 \\
\hline$\alpha$-terpineol & 1189 & 2.98 & 3.14 & 2.96 & 2.96 & 3.05 & 1.62 & 0.98 & 1.07 & 1.95 & 2.04 \\
\hline verbenone & 1204 & 0.17 & - & 0.11 & 0.11 & - & 0.14 & 0.20 & 0.27 & - & - \\
\hline \multicolumn{2}{|l|}{ Monoterpene (\%) } & 92.56 & 86.32 & 100 & 88.46 & 93.26 & 82.46 & 84.40 & 91.54 & 82.48 & 86.49 \\
\hline linalool acetate & 1257 & 0.12 & - & - & - & - & 1.96 & 0.87 & 2.15 & 0.11 & 3.09 \\
\hline lavandulil acetate & 1289 & 1.03 & 0.94 & 1.47 & 1.47 & 0.87 & 0.51 & - & 0.73 & - & 0.86 \\
\hline geranil acetate & 1383 & - & & - & - & 0.01 & 0.07 & - & - & 0.13 & 0.18 \\
\hline$\beta$-cariofilene & 1418 & 0.13 & - & 0.24 & 0.24 & 0.26 & 0.24 & - & 0.08 & 0.01 & 0.27 \\
\hline farnesene & 1420 & 0.71 & 0.56 & 0.49 & 0.49 & 0.75 & 1.48 & 1.56 & 0.97 & 1.32 & 1.61 \\
\hline germacrene D & 1480 & 0.03 & - & - & - & 0.11 & - & - & - & 0.18 & 0.24 \\
\hline isoval lavandulil & 1510 & 0.25 & 0.47 & 0.73 & 0.73 & 0.78 & 0.75 & 0.63 & 1.09 & 0.21 & 1.27 \\
\hline cariofilene oxyde & 1581 & 0.17 & 0.17 & 0.23 & 0.23 & 0.19 & 3.12 & 2.76 & 2.81 & 2.40 & 3.08 \\
\hline cadinool & 1640 & 2.05 & 2.14 & 1.84 & 1.84 & 2.03 & 0.15 & 0.09 & 0.34 & - & 0.63 \\
\hline$\alpha$-bisabolol & 1683 & - & 0.15 & - & - & - & 1.37 & - & 0.16 & 0.05 & 0.24 \\
\hline \multicolumn{2}{|c|}{ Sesquiterpenes (\%) } & 4.49 & 4.28 & 5 & 5 & 5 & 8.28 & 5.91 & 8.17 & 4.36 & 11.23 \\
\hline
\end{tabular}

${ }^{a}$ Retention indices from literature (Adams, 1995).

composition and proportion between leaves and inflorescences, standing out the camphor, which was reduced to approximately half and linalol, which was superior in leaves. Differences in composition and proportion of the chemical constituents in the essential oil by the luminosity conditions confirm observations of Mattana et al. (2010) who showed that, although the concentration of the major compound trans-nerolidol is reduced in shaded environments, the yield of the essential oil was favored.

The results indicate that cultivation outside soil can be an alternative for production of lavender biomass in the southern region of Brazil. Several 
harvests throughout the year are possible without replacing plants, in protected crop structures with high transmissivity to solar radiation. And both artificial shading and other factors that reduce transmissivity of the cover material should be avoided because they reduce inflorescence yield and oil yield. For industrial scale oil production purposes, green mass production schedules can be envisaged in order to extend the industrial processing period during the year. We concluded that, planting in the beginning of March, three consecutive harvests can be made in August (150 DAP), October (213 DAP) and February (320 DAP).

\section{REFERENCES}

ABDEL-HADY, NM; ABDALLAH, GM; IDRIS, NF. 2014. Phytochemical studies and in vivo antioxidant activity of two Lavandula species (Lamiaceae) against streptozotocin induced oxidative stress in albino rats. Journal of Biomedical and Pharmaceutical Research 3: 30-40.

ADAMS, RP. 1995. Identification of essential oil components by gas chromatography/mass spectroscopy. Illinois: Allured Publishing Corporation. 469p.

ADE-ADEMILUA, EO; OBI, HO; CRAKER, LE. 2013. Growth and essential oil yield of African Basil, Ocimum gratissimum, under light and water stress. Journal of Medicinally Active Plants 1: 143-149.

ALVARES, CA; STAPE, JL; SENTELHAS, PC; GONÇALVES, JLM; SPAROVEK, G. 2014. Koppen's climate classification map for Brazil. Meteorologische Zeitschrift 22: 711-728.

ALY, MM; AL-GHAMDI, M; BAFEEL, SO; KHEDR, AM. 2013. Antimicrobial qctivities and phytochemical analysis of the essential oil of Lavandula dentata and Plectranthus tenuiflorus, collected from Al Baha region, Saudi Arabia. Life Science Journal 10: 3302 3309.

BARROS, FMC; ZAMBARDA, EO;
HEINZMANN, BM. 2009. Variabilidade sazonal e biossíntese de terpenóides presentes no óleo essencial de Lippia alba (Mill.) N. E. Brown (Verbenaceae). Química Nova 32: 861-867.

BIASI, LA; DESCHAMPS, C. 2009. Plantas aromáticas: do cultivo à produção de óleo essencial. Curitiba: Layer Studio Gráfico e Editora Ltda. 160p.

BOUSMAHA, L; BEKKARA, FA; TOMI, F; CASANOVA, J. 2005. Advances in the chemical composition of Lavandula dentata $\mathrm{L}$. essential oil from Algeria. Journal of Essential Oil Research 17: 292-295.

BRANT, RS; PINTO, JEBP; ROSA, LF; ALBUQUERQUE, CJB; FERRI, PH; CORREAA, RM. 2009. Crescimento, teor e composição do óleo essencial de melissa cultivada sob malhas fotoconversoras. Ciência Rural 39: 1401-1407.

CHAGAS, JH; PINTO, JEBP; BERTOLUCCI, SKV; COSTA, AG; JESUS, HCR; ALVES, PB. 2013. Produção, teor e composição química do óleo essencial de hortelã-japonesa cultivada sob malhas fotoconversoras. Horticultura Brasileira 31: 297-303.

CHANG, X; ALDERSON, PG; WRIGHT, CJ. 2008. Solar irradiance level alters the growth of basil (Ocimum basilicum L.) and its content of volatile oils. Environmental and Experimental Botany 63: 216-223.

FAO Food and Agriculture Organization of the United Nations. 2013, 28 de março. Good agricultural practices for greenhouse vegetable crops. Available in: http://www.fao. org/3/a-i3284e.pdf

FRESCURA, VDS. 2014. Parâmetros fitoquímicos, genotóxicos e de crescimento de alecrim (Rosmarinus officinalis L.) em diferentes salinidades e doses de nitrogênio. Santa Maria: UFSM. 113p (Tese doutorado).

GOMES, PA; SOUZA, MF; JÚNIOR, ITS; JUNIOR, WGOC; FIGUEIREDO, LS; MARTINS, ER. 2009. Influência do sombreamento na produção de biomassa, óleo essencial e quantidade de tricomas glandulares em cidrão (Lippia citriodora Lam.). Biomas 22: 9-14.

HASSIOTIS, CN; NTANA, F; LAZARI, DM; POULIOS, S; VLACHONASIOS, KE. 2014. Environmental and developmental factors affect essential oil production and quality of Lavandula angustifolia during flowering period. Industrial Crops and Products 62:
359-366.

IMELOUANE, B; ELBACHIRI, A; WATHELET, JP; DUBOIS, J; AMHAMDI, H. 2010. Chemical composition, cytotoxic and antioxidant activity of the essential oil of Lavandula dentata. World Journal of Chemistry 5: 103-110.

MASETTO, MAM. 2009. Ácido giberélico e extrato de alga marinha na produtividade e composição do óleo essencial de lavanda (Lavandula dentata L.). Curitiba: UFPR. 96p (Dissertação mestrado).

MASETTO, MAM; DESCHAMPS, C; MÓGOR, AF; BIZZO, HR. 2011. Teor e composição do óleo essencial de inflorescências e folhas de Lavandula dentata $\mathrm{L}$. em diferentes estádios de desenvolvimento floral e épocas de colheita. Revista Brasileira de Plantas Medicinais 13: 413-421.

MATTANA, RS; VIEIRA, MAR; MARCHESE, JA; MING, LC; MARQUES, MOM. 2010. Shade level effects on yield and chemical composition of the leaf essential oil of Pothomorphe umbellata (L.) Miquel. Scientia Agricola 67: 414-418.

MCNAUGHTON, V. 2006. Lavender: the growers guide. Portland: Timber Press. 192p.

SERUDO, RN; ASSIS, IM; KLEHM, CS; SILVA, JF; FLORENCIO, V. 2013. Acúmulo de matéria seca e rendimento de óleo da planta Otacanthus azureus em função da luminosidade e adubação nitrogenada. Scientia Plena 9: 110-119.

SILVA, SM. 2015. Sistemas agrícolas e adubação na biomassa e óleo essencial de lavanda (Lavandula dentata L.). Uberlândia: UFU. $111 \mathrm{p}$ (Tese doutorado).

TOUATI, B; CHOGRANI, H; HASSEN, I; BOUSSAID, M; TOUMI, L; BRAHIM, NB. 2011. Chemical composition of the leaf and flower essential oils of Tunisian Lavandula dentata $\mathrm{L}$. (Lamiaceae). Chemistry \& Biodiversity 8: 1560-1569.

VERMA, RS; PADALIA, RC; CHAUHAN, A. 2015. Harvesting season and plant part dependent variations in the essential oil composition of Salvia officinalis L. grown in northern India. Journal of Herbal Medicine 5: $165-171$.

ZHELJAZKOV, VD; CANTRELL, CL; ASTATKIE, T; JELIAZKOVA, E. 2013. Distillation time effect on lavender essential oil yield and composition. Journal of Oleo Science 62: 195-199. 
SILVA, GO; PEREIRA, AS; AZEVEDO, FQ; CARVALHO, ADF. 2018. Genotypic selection of advanced potato clones by REML/BLUP. Horticultura Brasileira 36: 265-270. DOI: http://dx.doi.org/10.1590/S0102-053620180220

\section{Genotypic selection of advanced potato clones by REML/BLUP}

\section{Giovani O Silva ${ }^{1}$; Arione S Pereira ${ }^{2}$; Fernanda Q Azevedo ${ }^{2}$; Agnaldo DF Carvalho $^{3}$}

${ }^{1}$ Embrapa Hortaliças-SPM, Canoinhas-SC, Brazil; giovani.olegario@embrapa.br; ${ }^{2}$ Embrapa Clima Temperado, Pelotas-RS, Brazil; arione. pereira@embrapa.br; fernanda.azevedo@embrapa.br; ${ }^{3}$ Embrapa Hortaliças, Brasília-DF, Brazil; agnaldo.carvalho@embrapa.br

\begin{abstract}
Potato genotypes were evaluated in their performance, according to the genotype values for tuber yield traits. The experiments were carried out in Canoinhas and Pelotas, Brazil, in spring 2014. Eleven advanced clones and two commercial cultivars (Agata and Asterix) (check cultivars) were evaluated. A randomized complete block design with four replicates was used. Plots were harvested 110 days after planting, and evaluated for tuber yield components. The data were submitted to joint deviance analyzes using the REML/BLUP method. Clones F102-22-07 and F32-02-06 stood out positively for tuber yield. F102-22-07 showed high marketable tuber yield and average tuber weight, while clone F32-02-06 exhibited high marketable and total tuber yield. The superiority of these advanced clones in relation to the check cultivars, suggests their potential to be evaluated in other environments, aiming their release as new cultivars.
\end{abstract}

Keywords: Solanum tuberosum, plant breeding, genotypic values.

\section{RESUMO} BLUP

Seleção genotípica de clones avançados de batata via REML/

Verificou-se o desempenho de genótipos de batata de acordo com os valores genotípicos para caracteres de rendimento de tubérculos. Os experimentos foram realizados em Canoinhas-SC e Pelotas-RS, na primavera de 2014. Foram avaliados onze clones e duas cultivares comerciais (Agata e Asterix) (testemunhas), em delineamento experimental em blocos casualizados com quatro repetições. A colheita foi realizada aos 110 dias após o plantio, seguida das avaliações de caracteres de componentes do rendimento de tubérculos. Analisou-se a deviance conjunta, por meio do método REML/BLUP. Os clones F102-22-07 e F32-02-06 destacaram-se positivamente para rendimento de tubérculos. O clone F102-22-07 apresenta alto rendimento de tubérculos comerciais e tubérculos de elevada massa média, enquanto o clone F32-02-06 apresenta elevado rendimento total e comercial de tubérculos. A superioridade destes clones avançados em relação às cultivares testemunhas, sugere potencial dos mesmos para serem avaliados em outros ambientes, visando o lançamento como novas cultivares.

Palavras-chave: Solanum tuberosum, melhoramento genético, valores genotípicos.

Received on March 21, 2017; accepted on February 2, 2018

$\mathrm{D}$ evelopment of Brazilian potato cultivars adapted to growing conditions of the country producing regions and with resistance to main diseases, is the most viable alternative to increase yield and profitability of this crop for growers (Gadum et al., 2003).

The main potato cultivars grown in Brazil are of European origin and, being not well adapted to the Brazilian environment (Kooman \& Rabbinge, 1996; Menezes et al., 2001; Pinto et al., 2010), show shorter vegetative cycle and lower yield, besides suffering greater pressure from pathogens and pests when grown here. To overcome these difficulties, high amounts of inputs are used to reach good yield, which reduce crop sustainability.
Plants, as well as other living organisms, are affected by the environment (E), genotype $(\mathrm{G})$ and their interaction (GE). The GE interaction promotes significant differences in genotype's performance when grown under different environmental conditions (Mohammadi et al., 2007). The GE interaction plays a key role in breeding programs, as it may interfere with the adaptability and stability of genotypes in relation to the tested environments.

According to Borges et al. (2010), inferences about genetic materials in field experiments, in order to identify those to be released as cultivars, should be based on true genotypic values, that is, on genotypic and non-phenotypic means. These estimates can be obtained using the best linear unbiased prediction (BLUP) and the restricted maximum likelihood (REML) methods. However, according to Resende (2002b), the REML procedure is equivalent to ANOVA in cases where the experiments are simple and balanced and meet the assumptions of the latter.

There are several traits to be considered for potato breeding. Among them is the tuber yield, essential for growers to obtain economic profitability. For this trait, it is known that plants yielding high tuber number generally produce smaller tubers (Silva et al., 2012). Both, number and size of tubers, directly influence marketable tuber yield (Silva et al., 2006). So, selection for balance between tuber number and tuber 
size, is important.

The objective of this work was to verify the performance of potato clones according to genotype values for tuber yield traits.

\section{MATERIAL AND METHODS}

The experiments were installed in Canoinhas $\left(26^{\circ} \mathrm{S}, 50^{\circ} \mathrm{W}, 839 \mathrm{~m}\right.$ altitude), and in Pelotas $\left(31^{\circ} \mathrm{S}, 52^{\circ} \mathrm{W}, 50\right.$ $\mathrm{m}$ altitude), with planting dates at end August. Eleven advanced potato clones of Embrapa's breeding program were evaluated and compared to commercial check cultivars Agata and Asterix.

A randomized complete block design with four replications was used. Plots were composed of two 3.5-meter rows, 10 plants each. Seed tubers (type II: diameter between 40 and $50 \mathrm{~mm}$ ), after stored during eight months in cold chamber $\left(4.0 \pm 0.5^{\circ} \mathrm{C}\right)$, were used. Planting spacings were 75 $\mathrm{cm}$ between rows and $35 \mathrm{~cm}$ within plants. As fertilizer the commercial formula 5-30-10 of N-P-K was used, $2.5 \mathrm{t} \mathrm{ha}^{-1}$. Cultural and phytosanitary treatments followed recommendations for the region (Pereira, 2010). After plant senescence, approximately 110 days after planting, crops were harvested.

The evaluated yield component traits were number of marketable tubers plot $^{-1}$, (diameter above $45 \mathrm{~mm}$ ); total number of tubers plot $^{-1}$; mass of marketable tubers $\left(\mathrm{kg} \mathrm{plot}^{-1}\right)$; total mass of tubers $\left(\mathrm{kg} \mathrm{plot}^{-1}\right)$; and, average tuber weight ( $\mathrm{g}$ tuber $^{-1}$ ), obtained by dividing the total mass of tubers by total number of tubers.
The number of tubers was converted to number of tubers $\mathrm{ha}^{-1} / 1000$ and yield traits in $\mathrm{tha}^{-1}$.

Joint deviance analysis for each trait was performed to ascertain the significance of effects, and for the evaluation of genotype GE interaction using the REML/BLUP method (Henderson, 1975).

For joint deviance analysis for both environments, the statistical model used was:

$$
y=X_{r}+Z_{g}+W_{i}+e
$$

Where $y$ is the data vector, $r$ is the vector of the replication effects (assumed to be fixed) added to the general average, and all replicates of all environments, $g$ is the vector of genotypic effects (assumed to be random), $i$ is the vector of GE interaction effects (random), and the error vector (random). $X, Z$, and $W$ are the matrices of incidence that relate effects of $r, g$, and $i$ to the $y$ vector, respectively (Resende, 2002a).

SELEGEN software (Resende, 2002b) was used to perform these analyzes.

\section{RESULTS AND DISCUSSION}

The deviance analysis revealed significant differences $(\mathrm{p}<0.01)$ between genotypes for all evaluated traits (Table 1). There was also a significant effect of GE interaction for all traits, indicating that genotype performance was not similar at both sites (Table 1).

Phenotypic coefficients of variation (CV) were lower for tuber number and total tuber yield, and average tuber weight, ranging from 10.82 to $11.50 \%$. For marketable tuber number and marketable tuber yield, CVs were higher (23.25\% and $24.35 \%$, respectively). Considering that tuber yield is a quantitative trait, which usually suffers a great environmental influence (Silva et al., 2006), the precision of these experiments was adequate. $\mathrm{CV}$ values of these experiments are similar to those reported by Silva et al. (2006), which ranged from 17.31 to $21.03 \%$ for yield (total tuber mass), total number of tubers and average tuber mass, and to those verified by Bisognin et al. (2008), with values varying between 16.19 and $25.60 \%$, for the yield traits of potato clones of different sizes. Likewise, Costa et al. (2007) found CVs between 22.70 and $18.30 \%$, for total tuber yield and total tuber number, respectively.

The effects of genetic order on the phenotype observed by magnitudes of genotypic variances, however, indicate that selection based on these traits would be efficient (Table 1).

The adequacy of experimental precision was also confirmed by the selective accuracy, which was higher than $70 \%$ for most traits, except for the marketable tuber mass $(63 \%)$ (Table 1). According to Resende (2002a), the value of selection accuracy, which is the square root of average heritability, evidences precision in inferences of genotypic values, indicating suitability of the experimental conduction for identification of superior genotypes.

GE interaction was of great importance for all traits, as observed

Table 1. Values of the likelihood ratio test (LRT) of the joint deviance analysis for yield traits, of 13 potato genotypes evaluated in Pelotas and Canoinhas in spring 2014. Canoinhas, Embrapa, 2018.

\begin{tabular}{lccccc}
\hline Effect & MTN & MTY & TTN & TTY & ATW \\
\hline Genotype $^{1}$ & $66.78^{*}$ & $89.62^{*}$ & $90.45^{*}$ & $129.14^{*}$ & $80.00^{*}$ \\
Genotype x environment $^{1}$ & $31.49^{*}$ & $54.00^{*}$ & $38.94^{*}$ & $80.73^{*}$ & $40.65^{*}$ \\
Coef. determination of interaction $_{\text {Genetic correlation between environments }}$ & 0.45 & 0.59 & 0.41 & 0.59 & 0.49 \\
Acuracy in the selection & 0.37 & 0.26 & 0.49 & 0.33 & 0.37 \\
Coeficient of variation (\%) & 0.71 & 0.63 & 0.79 & 0.70 & 0.71 \\
General mean & 23.25 & 24.35 & 10.82 & 11.50 & 11.18 \\
\hline
\end{tabular}

${ }^{1}$ LRT values; * significant at $\mathrm{P}<0.01$ by the $\chi^{2}$ test with 1 degree of freedom. $\mathrm{MTN}=$ marketable tuber number $\left(\mathrm{ha}^{-1} / 1000\right)$; MTY $=$ marketable tuber yield $\left(\mathrm{t} \mathrm{ha}^{-1}\right)$; TTN $=$ total tuber number $\left(\mathrm{ha}^{-1} / 1000\right)$; TTY $=$ total tuber yield $\left(\mathrm{t} \mathrm{ha}^{-1}\right)$; ATW= average tuber weight $\left(\mathrm{g}\right.$ tuber $\left.{ }^{-1}\right)$. 
Table 2. Estimates of predicted genetic $(g)$ and genotypic values $(u+g)$ for ${ }^{1}$ Pelotas, ${ }^{2}$ Canoinhas and ${ }^{3}$ joint for both environments, and estimates of mean genotypic value $(u+g+g$ em $)$ of 13 potato genotypes for total tuber number $\left(\mathrm{ha}^{-1} / 1000\right)$ and total tuber yield $\left(\mathrm{t}\right.$ ha $\left.{ }^{-1}\right)$, in spring 2014. Canoinhas, Embrapa, 2018.

\begin{tabular}{|c|c|c|c|c|c|c|c|}
\hline \multirow{2}{*}{ Genotype } & $g^{1}$ & $u+g^{1}$ & $g^{2}$ & $u+g^{2}$ & $g^{3}$ & $u+g^{3}$ & $u+g+g e m$ \\
\hline & \multicolumn{7}{|c|}{ Total tuber number } \\
\hline Agata (check) & -147.15 & 346.15 & -90.49 & 409.84 & -79.77 & 417.04 & 375.69 \\
\hline Asterix (check) & 74.52 & 567.82 & -34.86 & 465.47 & 13.31 & 510.13 & 517.03 \\
\hline C2519-12-06 & -43.94 & 449.36 & -54.60 & 445.73 & -33.08 & 463.73 & 446.59 \\
\hline F102-22-07 & -84.78 & 408.52 & -86.89 & 413.44 & -57.63 & 439.18 & 409.31 \\
\hline F189-09-06 & -96.44 & 396.85 & 106.01 & 606.34 & 3.22 & 500.03 & 501.70 \\
\hline F208-01-06 & -91.06 & 402.24 & -86.90 & 413.43 & -59.74 & 437.07 & 406.11 \\
\hline F22-01-08 & 132.86 & 626.15 & -81.96 & 418.37 & 17.08 & 513.89 & 522.74 \\
\hline F23-11-06 & 171.45 & 664.75 & 23.02 & 523.35 & 65.28 & 562.09 & 595.92 \\
\hline F23-24-06 & 77.22 & 570.51 & 111.84 & 612.17 & 63.47 & 560.28 & 593.18 \\
\hline F31-05-08 & -68.17 & 425.12 & -30.81 & 469.52 & -33.23 & 463.58 & 446.36 \\
\hline F32-02-06 & 117.15 & 610.45 & 243.75 & 744.08 & 121.16 & 617.98 & 680.77 \\
\hline F32-11-06 & 51.19 & 544.49 & 66.09 & 566.42 & 39.37 & 536.19 & 556.59 \\
\hline \multirow[t]{2}{*}{ F38-03-07 } & -92.85 & 400.44 & -84.21 & 416.12 & -59.44 & 437.37 & 406.57 \\
\hline & \multicolumn{7}{|c|}{ Total tuber yield } \\
\hline Agata (check) & -7.12 & 11.20 & -14.67 & 17.84 & -5.52 & 19.90 & 14.41 \\
\hline Asterix (check) & 2.38 & 20.70 & -9.63 & 22.89 & -1.82 & 23.60 & 21.79 \\
\hline C2519-12-06 & -1.85 & 16.47 & -7.91 & 24.60 & -2.47 & 22.95 & 20.49 \\
\hline F102-22-07 & -0.67 & 17.65 & 7.46 & 39.98 & 1.71 & 27.13 & 28.83 \\
\hline F189-09-06 & -3.98 & 14.34 & 10.89 & 43.41 & 1.73 & 27.15 & 28.86 \\
\hline F208-01-06 & -6.46 & 11.86 & -5.55 & 26.96 & -3.05 & 22.37 & 19.33 \\
\hline F22-01-08 & 7.53 & 25.85 & -8.98 & 23.54 & -0.34 & 25.08 & 24.75 \\
\hline F23-11-06 & 3.31 & 21.63 & 4.83 & 37.35 & 2.06 & 27.48 & 29.53 \\
\hline F23-24-06 & 6.06 & 24.38 & 7.16 & 39.68 & 3.35 & 28.77 & 32.10 \\
\hline F31-05-08 & 0.58 & 18.90 & 4.50 & 37.02 & 1.28 & 26.70 & 27.97 \\
\hline F32-02-06 & 5.33 & 23.65 & 20.02 & 52.53 & 6.41 & 31.82 & 38.19 \\
\hline F32-11-06 & 0.61 & 18.93 & 4.41 & 36.92 & 1.27 & 26.68 & 27.94 \\
\hline F38-03-07 & -5.72 & 12.60 & -12.54 & 19.97 & -4.62 & 20.79 & 16.20 \\
\hline
\end{tabular}

by the proportion of variance of GE interaction on total phenotypic variance. It was calculated by the coefficient of determination of the interaction, which was close to $50 \%$ for most traits, and by genetic correlation between environments, which was reduced, varying from 0.26 for marketable tuber yield to 0.49 for total tuber number (Table 1). The low values of accuracy in selection based on joint analysis and genetic correlation between environments reinforce the importance of studying GE interaction to maximize gains in clone selection.
Both, tuber number and tuber size, directly influence marketable tuber yield (Silva et al., 2006). Therefore, it is important in selection process to find the balance between tuber number and tuber size. For total tuber number, the clones with highest estimates of free genetic values of the interaction for Pelotas and Canoinhas were F23-11-06, F23-24-06, F32-02-06 and F32-11-06, contributing with increases to general mean of $65.28,63.47,121.16$ and 39.37 tubers ha-1/1000, respectively, (Table 2). Predicted genotypic values, that is, the general mean capitalized by genetic values in selection of these genotypes, varied between 536.19 and 617.98 tubers ha ${ }^{-1} / 1000$. Cultivar Agata (check) had the worst performance for this trait, presenting the lowest genetic value. For this trait, 'Asterix' (check) and F22-01-08 were adapted specifically to Pelotas, and F189-09-06 to Canoinhas. Considering the average interaction of environments $(\mathrm{u}+\mathrm{g}+\mathrm{gem})$, which is equivalent to the average genotypic value of the two locations considering the interaction, clones F23-11-06, F2324-06, F32-02-06, and F32-11-06 had the highest values, 595.92, 593.18, 
Table 3. Estimates of predicted genetic $(g)$ and genotypic values $(u+g)$ for ${ }^{1}$ Pelotas, ${ }^{2}$ Canoinhas and ${ }^{3}$ joint for both environments, estimates of genotypic value $(u+g+$ gem $)$, of 13 potato genotypes for marketable tuber number $\left(\mathrm{ha}^{-1} / 1000\right)$ and marketable tuber yield $\left(\mathrm{t}\right.$ ha $\left.{ }^{-1}\right)$, in spring 2014. Canoinhas, Embrapa, 2018.

\begin{tabular}{|c|c|c|c|c|c|c|c|}
\hline \multirow{2}{*}{ Genotype } & $g^{1}$ & $u+g^{I}$ & $g^{2}$ & $u+g^{2}$ & $g^{3}$ & $u+g^{3}$ & $u+g+g e m$ \\
\hline & \multicolumn{7}{|c|}{ Marketable tuber number } \\
\hline Agata & -27.36 & 52.16 & -64.18 & 49.49 & -25.68 & 70.91 & 49.44 \\
\hline Asterix & -12.07 & 67.45 & -47.66 & 66.01 & -16.58 & 80.01 & 66.14 \\
\hline C2519-12-06 & -3.62 & 75.90 & -38.72 & 74.94 & -11.61 & 84.99 & 75.28 \\
\hline F102-22-07 & 24.14 & 103.66 & 40.78 & 154.44 & 18.36 & 114.95 & 130.30 \\
\hline F189-09-06 & -7.65 & 71.88 & 44.35 & 158.02 & 9.74 & 106.34 & 114.48 \\
\hline F208-01-06 & -13.28 & 66.25 & -0.31 & 113.36 & -4.09 & 92.51 & 89.09 \\
\hline F22-01-08 & 41.44 & 120.97 & -44.53 & 69.14 & 0.40 & 96.99 & 97.33 \\
\hline F23-11-06 & -24.14 & 55.38 & 17.11 & 130.77 & -2.63 & 93.96 & 91.76 \\
\hline F23-24-06 & 20.12 & 99.64 & 11.30 & 124.96 & 9.14 & 105.73 & 113.37 \\
\hline F31-05-08 & -1.21 & 78.32 & 34.53 & 148.19 & 9.01 & 105.61 & 113.15 \\
\hline F32-02-06 & 37.02 & 116.54 & 70.26 & 183.92 & 30.24 & 126.84 & 152.13 \\
\hline F32-11-06 & -6.44 & 73.09 & 22.92 & 136.58 & 4.28 & 100.88 & 104.46 \\
\hline \multirow[t]{2}{*}{ F38-03-07 } & -26.96 & 52.56 & -45.87 & 67.79 & -20.59 & 76.01 & 58.79 \\
\hline & \multicolumn{7}{|c|}{ Marketable tuber yield } \\
\hline Agata & -2.44 & 4.22 & -10.05 & 6.31 & -2.69 & 8.83 & 5.12 \\
\hline Asterix & -1.17 & 5.49 & -8.47 & 7.90 & -2.06 & 9.46 & 6.62 \\
\hline C2519-12-06 & -0.42 & 6.24 & -6.29 & 10.08 & -1.42 & 10.09 & 8.13 \\
\hline F102-22-07 & 2.25 & 8.91 & 11.71 & 28.07 & 2.99 & 14.50 & 18.63 \\
\hline F189-09-06 & -0.74 & 5.92 & 6.81 & 23.18 & 1.26 & 12.78 & 14.52 \\
\hline F208-01-06 & -2.29 & 4.37 & -0.76 & 15.61 & -0.69 & 10.82 & 9.86 \\
\hline F22-01-08 & 3.77 & 10.43 & -6.74 & 9.62 & -0.54 & 10.97 & 10.22 \\
\hline F23-11-06 & -1.91 & 4.75 & 2.79 & 19.15 & 0.14 & 11.66 & 11.85 \\
\hline F23-24-06 & 2.76 & 9.42 & 1.12 & 17.49 & 0.88 & 12.39 & 13.60 \\
\hline F31-05-08 & 0.61 & 7.26 & 5.64 & 22.00 & 1.33 & 12.84 & 14.68 \\
\hline F32-02-06 & 2.72 & 9.37 & 10.94 & 27.30 & 2.94 & 14.45 & 18.50 \\
\hline F32-11-06 & -0.68 & 5.98 & 2.19 & 18.56 & 0.30 & 11.82 & 12.24 \\
\hline F38-03-07 & -2.46 & 4.20 & -8.87 & 7.49 & -2.44 & 9.07 & 5.70 \\
\hline
\end{tabular}

680.77 and 556.59 tubers $\mathrm{ha}^{-1} / 1000$, respectively. In addition to high genetic value, these clones presented good performance for the environmental conditions considered in the calculation of the GE interaction.

For the best performing genotypes, a very similar situation was observed for total tuber yield and total tuber number, being F102-22-07 the only exception (Table 2). This clone presented a positive value for tuber yield in Canoinhas, but this was not true for total tuber number. Likewise, clone F32-11-06 in Pelotas did not stand out for total yield as much as for total tuber number. For total yield, the best clones were F2311-06, F23-24-06 and F32-02-06, with mean genotypic values considering the interaction of $29.53,32.10$ and $38.19 \mathrm{t} \mathrm{ha}^{-1}$, respectively, well above the average of the experiments $(25.42$ $\left.\mathrm{t} \mathrm{ha}^{-1}\right)$ and to expected mean of checks $\left(18.10 \mathrm{t} \mathrm{ha}^{-1}\right)$. Therefore, for total tuber number and total yield, F23-11-06, F2324-06 and F32-02-06 stood out from the other clones, both eliminating the GE interaction effect and considering its effects.

For marketable tuber number and marketable tuber yield, clones with highest genetic values for both tested locations were F102-22-07 and F3202-06, with estimated marketable tuber number of 130.30 and 152.13 tubers $\mathrm{ha}^{-1} / 1000$, and marketable tuber yield of 18.63 and $18.50 \mathrm{t} \mathrm{ha}^{-1}$, respectively, considering the interaction $(u+g+g e m)$ (Table 3). These yield values are on average $46.20 \%$ and $61.25 \%$ above the overall mean of the experiment for marketable tuber number and marketable tuber yield characters. Clones F22-01-08 and F23-24-06 presented higher marketable yields, 
Table 4. Estimates of predicted genetic $(g)$ and genotypic $(u+g)$ values for ${ }^{1}$ Pelotas, ${ }^{2}$ Canoinhas and ${ }^{3}$ joint for both environments, estimates of the mean genotypic value $(u+g+g e m)$, of 13 potato genotypes for average tuber weight $\left(\mathrm{g}\right.$ tuber $\left.{ }^{-1}\right)$, in spring 2014. Canoinhas, Embrapa, 2018.

\begin{tabular}{lccrcccc}
\hline Genotype & $\boldsymbol{g}^{\mathbf{1}}$ & $\boldsymbol{u}^{+\boldsymbol{g}^{\mathbf{1}}}$ & $\boldsymbol{g}^{\mathbf{2}}$ & $\boldsymbol{u}+\boldsymbol{g}^{\mathbf{2}}$ & $\boldsymbol{g}^{\mathbf{3}}$ & $\boldsymbol{u}^{+\boldsymbol{g}^{\mathbf{3}}}$ & $\boldsymbol{u + g + g e m}$ \\
\hline Agata & -4.18 & 32.86 & -19.31 & 45.59 & -6.44 & 44.53 & 38.98 \\
Asterix & -0.66 & 36.38 & -14.41 & 50.49 & -4.11 & 46.86 & 43.31 \\
C2519-12-06 & -0.21 & 36.83 & -9.09 & 55.81 & -2.54 & 48.43 & 46.24 \\
F102-22-07 & 6.07 & 43.11 & 31.33 & 96.23 & 10.24 & 61.21 & 70.05 \\
F189-09-06 & -0.72 & 36.32 & 5.76 & 70.66 & 1.37 & 52.34 & 53.52 \\
F208-01-06 & -6.82 & 30.22 & 0.86 & 65.76 & -1.68 & 49.29 & 47.84 \\
F22-01-08 & 3.83 & 40.87 & -6.64 & 58.26 & -0.74 & 50.23 & 49.60 \\
F23-11-06 & -3.97 & 33.07 & 6.45 & 71.35 & 0.65 & 51.62 & 52.17 \\
F23-24-06 & 5.24 & 42.28 & 1.02 & 65.93 & 1.75 & 52.72 & 54.23 \\
F31-05-08 & 7.19 & 44.23 & 14.15 & 79.05 & 5.87 & 56.84 & 61.91 \\
F32-02-06 & 1.50 & 38.54 & 5.81 & 70.72 & 2.01 & 52.98 & 54.71 \\
F32-11-06 & -2.23 & 34.81 & 0.10 & 65.01 & -0.60 & 50.38 & 49.86 \\
F38-03-07 & -5.05 & 31.99 & -16.02 & 48.88 & -5.78 & 45.19 & 40.20 \\
\hline
\end{tabular}

specifically for Pelotas, while F102-2207 and F32-02-06 were more adapted to Canoinhas.

For average tuber weight, which correlates with average tuber size, higher genetic values were observed for both locations, for clones F102-22-07 and F31-05-08, with mean genotypic values, considering GE interaction, of 70.05 and $61.89 \mathrm{~g}^{\text {tuber }}{ }^{-1}$, respectively (Table 4).

Thus, considering all tuber yield traits, clones that most stood out positively for the two locations were F102-22-07 and F32-02-06. Although not presenting high total tuber yield, clone F102-22-07 had high marketable tuber yield and high average tuber weight. On the other hand, Clone F3202-06, although not having the highest averages tuber yield, showed high total and marketable tuber yield.

Considering marketable tuber yield, $5.87 \mathrm{t} \mathrm{ha}^{-1}$ was the mean of check cultivars Agata and Asterix, cultivars widely grown in the country. Means for check cultivars are similar to those reported by Silva et al. (2016) in Canoinhas, based on a two-year experiment, observed marketable tuber yield of 7.54 and $9.47 \mathrm{t} \mathrm{ha}^{-1}$ for 'Agata' and 'Asterix', respectively. Also Silva et al. (2016b), found averages of 5.06 and $7.14 \mathrm{t} \mathrm{ha}^{-1}$ in Pelotas, for cultivars Agata and Asterix, respectively.
The mean marketable tuber yield of clones F102-22-07 and F32-02-06 was $18.56 \mathrm{t} \mathrm{ha}^{-1}$, therefore, well above means observed for the check cultivars. This superiority indicates potential of these clones to be released in the future as new cultivars, after proving their performance in further yield trials to be carried out in different potato growing regions of the country.

The clones F102-22-07 and F32-0206 stood out positively for tuber yield. F102-22-07 showed high marketable tuber yield and average tuber weight, while clone F32-02-06 exhibited high marketable and total tuber yield. The superiority of these advanced clones in relation to the check cultivars, suggests their potential to be evaluated in other environments, aiming their release as new cultivars.

\section{REFERENCES}

BORGES, V; FERREIRA, PV; SOARES, L; SANTOS, GM; SANTOS, AMM. 2010. Seleção de clones de batata-doce pelo procedimento REML/BLUP. Acta Scientiarum Agronomy 32: 643-649.

BISOGNIN, DA; MÜLLER, DR; STRECK, NA; ANDRIOLO, JL; SAUSEN, D. 2008. Desenvolvimento e rendimento de clones de batata na primavera e no outono. Pesquisa Agropecuária Brasileira 43: 699-705.

COSTA, LC; BISOGNIN, DA; ANDRIOLO, JL; RITTER, CEL; BANDINELLI, MG. 2007.
Identificação de clones de batata com potencial para mesa e adaptados para os cultivos de outono e primavera do Rio Grande do Sul. Ciência e Natura 29: 93-104.

CRUZ, CD; REGAZZI, AJ; CARNEIRO, PCS. 2012. Modelos biométricos aplicados ao melhoramento genético. Viçosa: Editora UFV. 514p.

GADUM, J; PINTO, CABP; RIOS, MCD. 2003. Desempenho agronômico e reação de clones de batata (Solanum tuberosum L.) ao PVY. Ciência e Agrotecnologia 27: 1484-1492.

HENDERSON, CR. 1975. Best linear estimation and prediction under a selection model. Biometrics 31: 423-447.

KOOMAN, PL; RABBINGE, R. 1996. An analysis of the relation between dry matter allocation to the tuber and earliness of a potato crop. Annals of Botany 77: 235-242.

MENEZES, CB; PINTO, CABP; NURMBERG, PL; LAMBERT, ES. 2001. Combining ability of potato genotypes for cool and warm seasons in Brazil. Crop Breeding and Applied Biotechnology 1: 145-157.

MOHAMMADI, R; HAGHPARAST, R; AGHAEE, M; ROSTAEE, M; POURDAD, SS. 2007. Biplot analysis of multi-environment trials for identification of winter wheat megaenvironments in Iran. World Journal of Agricultural Sciences 3: 475-480.

PEREIRA AS (org). 2010. Produção de batata no Rio Grande do Sul. Sistema de Produção, 19. Pelotas: Embrapa Clima Temperado. 95p.

PINTO, CABP; TEIXEIRA, AL; NEDER, DG; ARAÚJO, RR; SOARES, ARO; RIBEIRO, GHMR; LEPRE, AL. 2010. Potencial de clones elite de batata como novas cultivares para Minas Gerais. Horticultura Brasileira 28: 399-405.

RESENDE, MDV. 2002a. Genética biométrica e estatística no melhoramento de plantas perenes. Brasília: Embrapa Informação Tecnológica. $975 \mathrm{p}$ 
RESENDE, MDV. 2002b. Software SelegenREML/BLUP. Curitiba: Embrapa Florestas. $67 \mathrm{p}$.

SILVA, GO; SOUZA, VQ; PEREIRA, AS; CARVALHO, FIF; FRITSCHE-NETO, R. 2006. Early generation selection for tuber appearance affects potato yield components. Crop Breeding and Applied Biotechnology
6: 73-78.

SILVA, GO; CASTRO, CM; TERRES, LR; ROHR, A; SUINAGA, FA; PEREIRA, AS. 2012. Desempenho agronômico de clones elite de batata. Horticultura Brasileira 30: 557-560. SILVA, GO; CARVALHO, ADF; SILVA, SZ; PONIJALEKI, RS; SILVA, AS. 2016a. Desempenho genotípico de clones de batata via modelos mistos. Revista Brasileira de Ciências Agrárias 11: 259-266.

SILVA, GO; PEREIRA, AS; AZEVEDO, FQ; CARVALHO, ADF. 2016. Avaliação de clones de batata para caracteres de rendimento e qualidade de fritura. Revista Latinoamericana de la Papa 20: 37-44. 
ZANIN, DS; RESENDE, JTV; ZEIST, AR; OLIVEIRA, JRF; HENSCHEL, JM; LIMA FILHO, RB. 2018. Selection of processing tomato genotypes resistant to two spotted spider mite. Horticultura Brasileira 36: 271-275. DOI: http://dx.doi.org/10.1590/S0102-053620180221

\title{
Selection of processing tomato genotypes resistant to two spotted spider mite
}

\author{
Daniel S Zanin ${ }^{1}$; Juliano TV Resende²; André R Zeist²; João RF Oliveira²; Juliane M Henschel ${ }^{3}$; Renato B \\ Lima Filho ${ }^{1}$
}

${ }^{1}$ Universidade do Estado de Santa Catarina (UDESC), Lages-SC, Brazil; dsuekzanin@gmail.com (corresponding author); delimafilho. renato@yahoo.com.br; ${ }^{2}$ Universidade Estadual do Centro-Oeste (UNICENTRO), Guarapuava-PR, Brazil; jresende@unicentro.br; andre. zeist@bol.com.br; joaoroliveira@yahoo.com.br; ${ }^{3}$ Universidade Federal de Viçosa(UFV), Viçosa-MG, Brazil; juliane_henschel@hotmail.com

\begin{abstract}
One of the major problems in cultivation of tomato is the occurrence of pests and diseases. The objective of the research was to select genotypes from the second generation of the first backcross $\left(\mathrm{F}_{2} \mathrm{BC}_{1}\right)$ between the tomato cultivar for processing S. lycopersicum (cv. Redenção) and the wild access $S$. habrochaites var. hirsutum (PI-127826), with high levels of zingiberene (ZGB), resistant to the two spotted spider mite Tetranychus urticae (Acari: Tetranychidae). From the $\mathrm{F}_{2} \mathrm{BC}_{1}$ population. The ZGB content was quantified and five plants with high zingiberene selected (RVTZ 2011-079-117, RVTZ 2011-079-185, RVTZ 2011-079-335, RVTZ 2011-079-345 and RVTZ 2011-079-503) and four with low zingiberene content (RVTZ 2011-079-417, RVTZ 2011-331-460, RVTZ 2011-079-538 and RVTZ 2011-079-548) were selected. Genotypes selected for high and low ZGB content and the parentals $S$. habrochaites var. hirsutum access PI-127826 and 'Redenção' were evaluated for repellency to the two spotted spider mite. There was a significant and inverse correlation between ZGB content and average distances travelled by mites on tomato leaflets. The genotypes of the $\mathrm{F}_{2} \mathrm{BC}_{1}$ generation with high zingiberene levels RVTZ 2011-079-117, RVTZ 2011-079-185, RVTZ 2011-079-335, RVTZ 2011-079-345 and RVTZ 2011-079-503 are promising for progress in achieving resistant lines to arthropod pests. Among them RVTZ 2011-079-117 stands out for resistance to two spotted spider mite.
\end{abstract}

Keywords: Solanum lycopersicum, Solanum habrochaites var. hirsutum, Tetranychus urticae, genetic breeding, zingiberene.

\section{RESUMO}

Seleção de genótipos de tomateiro para processamento, resistentes ao ácaro-rajado

Um dos principais desafios da cadeia produtiva de tomates é a incidência de problemas fitossanitários, os quais resultam em grande aplicação de agrotóxicos, podendo causar problemas ao ambiente e à saúde de agricultores e consumidores. O objetivo deste trabalho foi selecionar genótipos de segunda geração do primeiro retrocruzamento $\left(\mathrm{F}_{2} \mathrm{RC}_{1}\right)$ entre a cultivar de tomateiro para processamento $S$. lycopersicum cultivar Redenção e o acesso silvestre $S$. habrochaites var. hirsutum (PI-127826), com elevados teores de zingibereno (ZGB), resistentes ao ácaro Tetranychus urticae. Da população $\mathrm{F}_{2} \mathrm{RC}_{1}$ foi quantificado o teor de $\mathrm{ZGB}$ e selecionadas cinco plantas com alto teor deste aleloquímico (RVTZ 2011-079-117, RVTZ 2011-079-185, RVTZ 2011-079-335, RVTZ 2011-079-345 e RVTZ 2011-079-503) e quatro com baixo teor (RVTZ 2011-079-417, RVTZ 2011-331-460, RVTZ 2011-079-538 e RVTZ 2011-079-548). Genótipos selecionados para altos e baixos teores de ZGB e, os parentais $S$. habrochaites var. hirsutum acesso PI-127826 e 'Redenção' foram avaliados quanto à repelência ao ácaro T. urticae. Houve correlação significativa e inversamente proporcional entre teor de ZGB e as distâncias médias percorridas pelos ácaros em folíolos de tomateiro. Os genótipos da geração $\mathrm{F}_{2} \mathrm{RC}_{1}$ com altos teores de zingibereno RVTZ 2011-079-117, RVTZ 2011-079-185, RVTZ 2011-079-335, RVTZ 2011-079-345 e RVTZ 2011-079-503 são promissores para avanços na obtenção de linhagens resistentes a artrópodes-praga. Dentre eles, o genótipo RVTZ 2011-079-117 destacou-se para resistência ao ácaro-rajado.

Palavras-chave: Solanum lycopersicum, Solanum habrochaites var. hirsutum, Tetranychus urticae, melhoramento genético, zingibereno.

Received on June 20, 2017; accepted on December 20, 2017

$\mathrm{T}_{\mathrm{s}}^{\mathrm{h}}$ he tomato (Solanum lycopersicum) is one of the most cultivated vegetables used for fresh consumption throughout the world. It also has largescale use in the agro-industry for food. Tomato for fresh consumption is cultivated in small and medium-sized properties, while tomato for processing is typically cultivated in large areas
(Gameiro et al., 2007). With industries in all consumer centers the processing of tomato is of global importance (Ubierna et al., 2010). It is one of the main industrialized vegetable in the world.

Frequent occurrences of phytosanitary problems affect the growth and development of tomato, placing it at a high risk for losses during the production cycle. Among the major arthropod pests, two spotted spider mites (Tetranychus urticae) are one of the most conspicuous (Silva et al., 2009).

The two spotted spider mite, although considered a secondary pest of tomato, is becoming increasingly important as the tomato plant provides favorable 
conditions for their reproduction and development (Lucini et al., 2016). In high infestation conditions, the major damages caused to the culture are drying of leaves and premature ripening of the fruits (Attia et al., 2013). Chemicals, insecticides, and miticides are the most widely used form of pest control. However, intensive use of agrochemicals can damage the environment and affect the health of farmers and consumers (Silva et al., 2009). An alternative to this is the introduction of genetic resistance in plants through crosses with wild genotypes rich in allelochemicals, compounds produced during secondary metabolism (Maluf et al., 2001; Silva et al., 2009; Neiva et al., 2013; Lima et al., 2015, 2016).

The resistance to arthropod pests in wild tomato plants has often been associated with the production and exudation of allelochemicals by glandular trichomes present in stems, leaves, and fruits (Lucini et al., 2016). Acyl sugar is the major allelochemical produced by the wild species Solanum pennellii (Dias et al., 2016) and Solanum galapagense, while the species Solanum habrochaites produces two allelochemicals, 2-tridecanone and zingiberene (Baldin et al., 2005; Oliveira et al., 2012; Lima et al., 2015).

Generally, studies about the mechanisms and resistance levels in parental genotypes of $S$. habrochaites var. hirsutum in relation to twostriped mite (Weston et al., 1989) and whitefly (Fancelli et al., 2005) are related to the presence of trichomes in which sesquiterpene zingiberene is produced. The production of segregating generations can allow separation and evaluation of multiple mechanisms of resistance that may occur in plants. Furthermore, biological and behavioral bioassays are important in breeding programs in order to determine the degree of resistance of the resulting genotypes in relation to these herbivores (Carter \& Snyder, 1985).

The zingiberene (ZGB) is among the most studied allelochemicals, providing satisfactory levels of resistance to the tomato leaf miner Tuta absoluta (Lepidoptera: Gelechiidae) (Lima et al., 2015), whitefly (Baldin et al., 2005), two spotted spider mite (Silva et al., 2009), and red spider mite Tetranychus evansi (Acari:Tetranychidae) (Maluf et al., 2001). It is a sesquiterpene whose production occurs mainly in glandular trichomes, of which types IV and VI are present in large quantities in the leaf epidermis of the wild genotype $S$. habrochaites var. hirsutum PI-127826 (Gonçalves et al., 2006).

The objective of this study was to select genotypes from the second generation of the first backcross $\left(\mathrm{F}_{2} \mathrm{BC}_{1}\right)$ between the tomato cultivar $S$. lycopersicum 'Redenção' and the wild access S. habrochaites var. hirsutum PI-127826, with high levels of ZGB that helps plants to resist to two spotted spider mite attack.

\section{MATERIAL AND METHODS}

The experiments were conducted during 2013 and 2014 in the Vegetable Crops Sector of the Department of Agriculture at the Universidade Estadual do Centro-Oeste (UNICENTRO) $\left(25^{\circ} 23^{\prime} 00^{\prime \prime} \mathrm{S}\right.$; 51 ${ }^{\circ} 29^{\prime} 39^{\prime \prime} \mathrm{W}$; altitude $1.024 \mathrm{~m})$. The climate is mesothermal humid subtropical $(\mathrm{Cfb})$, with moderate summers and frequent and severe frosts in winter.

The segregating $\mathrm{F}_{2}$ genotypes were obtained from the interspecific cross between the $S$. lycopersicum cultivar 'Redenção,'strain with low levels of ZGB and characteristics for processing, and the wild species $S$. habrochaites var. hirsutum access PI-127826, genotype with high levels of ZGB.

Quantification of the ZGB content of $\mathrm{F}_{2}$ generation was performed on leaf discs collected from young fully expanded leaflets located in the upper third of the plants totaling $6 \mathrm{~cm}^{2}$ of leaf area (Freitas et al., 2000). For ZGB extraction, $2 \mathrm{~mL}$ of distilled hexane was added to the leaf discs in open glass test tubes and shaken for 40 seconds. Subsequently the samples were quantified by spectrophotometric reading (Cary $100 \mathrm{UV}$-Vis) with absorbance at wavelength $270 \mathrm{~nm}$. The obtained values were then calculated in $\mathrm{mmol} / \mathrm{cm}^{2}$ of leaf area. The ZGB concentrations in the leaflets are directly proportional to the absorbance; higher absorbance values reflect greater ZGB contents.

To obtain the $\mathrm{F}_{2} \mathrm{BC}_{1}$ population, backcrossing was conducted in selected plants of the $F_{2}$ generation (with high levels of ZGB) with the recurring female cultivar 'Redenção'. The obtained fruits from backcross were collected and the $\mathrm{F}_{1} \mathrm{BC}_{1}$ seeds retrieved. The $\mathrm{F}_{2} \mathrm{BC}_{1}$ population was obtained through selffertilization of the $\mathrm{F}_{1} \mathrm{BC}_{1}$ generation.

In $\mathrm{F}_{2} \mathrm{BC}_{1}$ generation, by using the same methodology used in the quantification of $\mathrm{ZGB}$ in the $\mathrm{F}_{2}$ generation, from a total of 600 evaluated plants, there were five with high ZGB content (RVTZ 2011-079-117, RVTZ 2011-079-185, RVTZ 2011-079-335, RVTZ 2011-079-345, and RVTZ 2011079-503) and four with low content which were selected (RVTZ 2011-079417, RVTZ 2011-331-460, RVTZ 2011079-538, and RVTZ 2011-079-548). Plants with contrasting ZGB contents were cloned by rooting of axillary shoots in polystyrene trays consisting of 128 cells filled with commercial substrate Mecplant ${ }^{\circledR}$. Sowing of the cultivar 'Redenção' was held concurrently with cloning, and the sowing of wild species S. habrochaites var. hirsutum access PI-127826 was carried out fifteen days earlier. Difference in emergence and growth was the reason for staggered sowing.

At 21 days after cloning, when plants had formed roots and the parentals had between three and five true leaves, the genotypes with contrasting ZGB content (high ZGB content, S. habrochaites var. hirsutum PI-127826, and low ZGB content, S. lycopersicum 'Redenção') as well as the control, were transplanted in low density polyethylene jars of $10 \mathrm{dm}^{3}$ containing sieved soil.

To evaluate the plant repellency to T. urticae, an adapted methodology was used (Weston \& Snyder, 1990). Mites were collected in snap bean plants and placed for breeding in tomato plants, cultivar Santa Cruz Kada ${ }^{\circledR}$ in greenhouse. A randomized block design with four replications was used to evaluate the selected tomato genotypes of $\mathrm{F}_{2} \mathrm{BC}_{1}$ for high and low $\mathrm{ZGB}$ content, to the parentals $S$. habrochaites var. 
hirsutum access PI-127826 and to the commercial cultivar 'Redenção'. Each replication consisted of one plant. About 40 days after transplanting, three fully expanded young leaflets of similar size were collected, from upper third of each plant.

Each of the leaflets was fixed at the central region, with the abaxial side up, on a sheet of A4 paper (210 x $297 \mathrm{~mm}$ ) and placed on expanded polystyrene boards with the aid of a metallic tack ( $9 \mathrm{~mm}$ diameter). On each metal thumbtack, with help of a fine brush, ten adult female mites obtained from a laboratory rearing were released. The distance covered by the mites ( $\mathrm{mm}$ ) from the center of the tack was measured after 20, 40 and $60 \mathrm{~min}$ of exposure. The maximum gap between the center of the thumbtack and longest distance from the end of the leaflet was taken as distance traveled by the mite after it left the leaflet. Mites that remained on the metal thumbtack were considered to have traversed a zero distance. We considered small distances covered by mites as indicative of greater level of repellency.

The data obtained in the tests were submitted to the Shapiro-Wilk normality test and the Lèvene test of homogeneity of variances. Obtained results were subjected to transformation by square root $\left(\mathrm{x}^{1 / 2}\right)$. Data were submitted to analysis of variation and averages grouped by Scott-Knott test, with $\mathrm{p}<0.05$, using the statistical program Sisvar (Ferreira, 2008).

Pearson correlations were estimated between the results of the test of resistance to pests and the ZGB levels of the genotypes using the statistical program Assistat 7.7 Beta (Silva, 2014). Contrasts of interest were estimated for each variable, including control and $\mathrm{F}_{2} \mathrm{BC}_{1}$ genotypes with contrasting levels of ZGB, through software Sisvar (Ferreira, 2008).

\section{RESULTS AND DISCUSSION}

There were significant differences among genotypes for average distances traveled by mites on abaxial surface of leaflets (Table 1). At 20 and $60 \mathrm{~min}$, two of the genotypes evaluated with high ZGB content (RVTZ 2011-079-345 and 2011-079-503 RVTZ) demonstrated the lowest distance traveled by the mites, which corresponded to the control with high content of ZGB, PI-127826: 1.95, 1.30 , and $1.22 \mathrm{~mm}$ for $20 \mathrm{~min}$ and 2.56, 2.66 and $2.70 \mathrm{~mm}$ for $60 \mathrm{~min}$, respectively. At $40 \mathrm{~min}$, all genotypes with high ZGB content (RVTZ 2011079-345, RVTZ 2011-079-503, RVTZ 2011-079-185, RVTZ 2011-079-117, and RVTZ 2011-079-335) showed results that did not differ from the wild parental PI-127826, with 1.80 , $2.22,3.64,3.83,6.28$ and $2.22 \mathrm{~mm}$, respectively. At all evaluated exposure times, genotypes selected for high levels of ZGB had obtained lower distances traveled by the mites in comparison with the parental 'Redenção'.

There was a significant and inversely proportional correlation between the
ZGB content and the average distances traveled by the mites on the tomato leaflets. The group of plants $\mathrm{F}_{2} \mathrm{BC}_{1}$ with high ZGB content did not differ from wild type control PI-127826 (Table 1). However, the cultivar 'Redenção', presented the highest average distances traveled by mites in the leaflets, followed by the group with low ZGB content.

The bioassay made with two spotted spider mite allowed clearly observe the sharp contrast between $S$. lycopersicum 'Redenção' and genotypes with low ZGB content when compared to selected genotypes for high content of allelochemical (Table 1).

The results obtained in this study are in agreement with those presented by Gonçalves et al. (2006) and Lima et al. (2016). These authors found a positive correlation between ZGB content and resistance to $T$. evansi and T. urticae, and to Tuta absoluta

Table 1. Mean distance travelled ( $\mathrm{mm}$ ) by two spotted spider mites after 20, 40 and 60 minutes of exposure to the abaxial surface of leaflets in tomato genotypes $S$. lycopersicum cv. 'Redenção', S. habrochaites var. hirsutum PI-127826 and selected $\mathrm{F}_{2} \mathrm{BC}_{1}$ plants with high and low zingiberene (ZGB) content. Guarapuava, UNICENTRO, 2015.

\begin{tabular}{|c|c|c|c|c|}
\hline \multirow{2}{*}{ Genotype } & \multirow{2}{*}{$\begin{array}{c}\text { Zingiberene } \\
\text { content } \\
(\mathrm{Abs})^{1}\end{array}$} & \multicolumn{3}{|c|}{ Travelled distance $(\mathrm{mm})$} \\
\hline & & $20 \mathrm{~min}$ & $40 \mathrm{~min}$ & $60 \mathrm{~min}$ \\
\hline S. habrochaites PI-127826 & 0.338 & $1.22 \mathrm{a}^{2}$ & $2.22 \mathrm{a}$ & $2.70 \mathrm{a}$ \\
\hline RVTZ 2011-079-117 (high) & 0.216 & $2.46 \mathrm{~b}$ & $3.83 \mathrm{a}$ & $5.24 \mathrm{~b}$ \\
\hline RVTZ 2011-079-185 (high) & 0.346 & $3.10 \mathrm{~b}$ & $3.64 \mathrm{a}$ & $4.83 \mathrm{~b}$ \\
\hline RVTZ 2011-079-335 (high) & 0.216 & $4.71 \mathrm{~b}$ & $6.28 \mathrm{a}$ & $7.72 \mathrm{~b}$ \\
\hline RVTZ 2011-079-345 (high) & 0.197 & $1.95 \mathrm{a}$ & $1.80 \mathrm{a}$ & $2.56 \mathrm{a}$ \\
\hline RVTZ 2011-079-503 (high) & 0.285 & $1.30 \mathrm{a}$ & $2.22 \mathrm{a}$ & $2.66 \mathrm{a}$ \\
\hline RVTZ 2011-079-417 (low) & 0.038 & $15.19 \mathrm{c}$ & $16.26 \mathrm{~b}$ & $17.26 \mathrm{c}$ \\
\hline RVTZ 2011-331-460 (low) & 0.039 & $21.63 \mathrm{c}$ & $21.88 \mathrm{~b}$ & $22.95 \mathrm{c}$ \\
\hline RVTZ 2011-331-538 (low) & 0.029 & $14.94 \mathrm{c}$ & $19.77 \mathrm{~b}$ & $19.71 \mathrm{c}$ \\
\hline RVTZ 2011-331-548 (low) & 0.025 & $22.86 \mathrm{c}$ & $26.14 \mathrm{c}$ & $27.39 \mathrm{~d}$ \\
\hline S. lycopersicum cv. Redenção & 0.103 & $33.58 \mathrm{~d}$ & $32.46 \mathrm{c}$ & $34.90 \mathrm{~d}$ \\
\hline $\mathrm{CV}(\%)$ & 84.56 & 28.63 & 24.87 & 24.94 \\
\hline Correlation with ZGB content & & $-0.82^{* *}$ & $-0.83^{* *}$ & $-0.83^{* *}$ \\
\hline \multicolumn{2}{|c|}{ Comparison of contrast of interest estimative } & 20 min & $40 \mathrm{~min}$ & $60 \mathrm{~min}$ \\
\hline \multicolumn{2}{|c|}{ Genotypes high vs. genotypes low } & $-14.60^{* *}$ & $-15.96^{* *}$ & $-15.98^{* *}$ \\
\hline \multicolumn{2}{|l|}{ PI-127826 vs. genotypes high } & $-2.83^{\mathrm{ns}}$ & $-2.84^{\mathrm{ns}}$ & $-3.15^{\text {ns }}$ \\
\hline \multicolumn{2}{|l|}{ PI-127826 vs. genotypes low } & $-17.44^{* *}$ & $-18.79^{* *}$ & $-19.13^{* *}$ \\
\hline \multicolumn{2}{|l|}{ Redenção vs. genotypes high } & $29.53^{* *}$ & $27.41^{* *}$ & $29.05^{* *}$ \\
\hline \multicolumn{2}{|l|}{ Redenção vs. Genotypes low } & $14.92^{* *}$ & $11.45^{* *}$ & $13.07^{* *}$ \\
\hline
\end{tabular}

${ }^{1} \mathrm{ZGB}$ content at $270 \mathrm{~nm} ;{ }^{2}$ Means followed by same letters in the column belong to the same group, Scott-Knott test, $\mathrm{p}<0,05 ;{ }^{* *}$ significant correlation, Student t test, $\mathrm{p}<0,01 ;{ }^{* *}$ significant

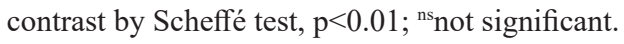


(Lepidoptera: Gelechiidae) in genotypes originated from the interspecific cross between $S$. habrochaites var. hirsutum and S. lycoperscicum TOM-556 and 'Redenção', respectively.

In most studies on tomato resistance, repellency estimated time is given by the mite permanence on the surface of a tack when exposed to allelochemicals. In the present study, the results confirmed this information, and the genotypes with high ZGB content have higher degree of repellency in bioassays.

Silva et al. (2009) found a higher degree of repellency to spider mite in double heterozygotic genotypes with a high ZGB content and acyl sugars, compared to the commercial controls. Maluf et al. (2001) considered ZGB the main factor responsible for the resistance to $T$. evansi in interspecific hybrids originating from the crossing between $S$. habrochaites var. hirsutum x S. lycopersicum.

Toscano et al. (2002) observed that the genotype PI-127826 have trichomes type I, IV, Va, VIc and VII. Glandular trichomes type IV along with the type VI, are responsible for production of the allelochemical ZGB (Gonçalves et al., 2006). These trichomes are present in low concentration in $S$. lycopersicum 'Redenção' (Lucini et al., 2015). According to Alba et al. (2009), glandular trichomes type IV are responsible to reduce oviposition of females and increase repellency and mortality of adults of two spotted spider mites on leaflets of tomato plants, by producing allelochemicals such as acylsugars. Figueiredo et al. (2013) showed that high densities of glandular trichomes on abaxial surface of strawberry leaflets decrease mobility of adults of two spotted spider mites. These trichomes promote resistance or no preference or antixenosis type, in which plants do not present attractive to the pest for basic functions such as shelter, food, oviposition and other essential activities (Lucini et al., 2015).

High resistance levels against two spotted spider mite in genotypes with high levels of allelochemicals is a favorable condition within the integrated pest management, because it facilitates the control, reducing the amount of chemicals used and simultaneously contributing to the reduction of production costs (Alba et $a l ., 2009)$. The role of ZGB and other alellochemicals in promoting resistance to pests has been confirmed in other studies. Silva et al. (2009) found that heterozygotic tomato genotypes rich in ZGB and double heterozygotic genotypes with high levels of ZGB and acyl sugars had fewer whitefly eggs, lower whitefly nymphs survival and lower distances traveled by two spotted spider mites on the leaflets, compared to commercial controls, suggesting a kind of no preference resistance for feeding and/or antibiosis. Neiva et al. (2013) obtained higher resistance to whitefly in tomato lines rich in acyl sugars, ZGB and 2-tridecanone, in comparison to the genotypes with low contents of these compounds. Rakha et al. (2017) observed that wild tomato genotypes with high density of type IV glandular trichomes were less preferred by two spotted spider mites adults for oviposition, feeding or shelter, and suffered less damage on leaves in comparison with a commercial cultivar, used as a control.

This study demonstrated that the indirect selection of genotypes with high levels of ZGB presents efficiency, enabling accelerating the process of selection of genotypes resistant to arthropod pests. According to Gonçalves et al. (2006), selecting through allelochemical content can be more efficient in obtaining genotypes with higher arthropod resistance levels in tomato plants when compared with bioassays using insects.

Tomato genotypes $\mathrm{F}_{2} \mathrm{BC}_{1}$ with high levels of ZGB, RVTZ 2011-079-117, RVTZ 2011-079-185, RVTZ 2011079-335, RVTZ 2011-079-345 and RVTZ 2011-079-503 presented shorter average distances traveled by mite $T$. urticae on the abaxial surface of the leaflets. Thus, these genotypes can be used in future backcrossing using the cultivar 'Redenção' as a recurrent parent, thus aiming to increase the agronomic characteristics and maintain the resistance to arthropod pests.

In conclusion, genotypes of $\mathrm{F}_{2} \mathrm{BC}_{1}$ generation with high zingiberene levels
RVTZ 2011-079-117, RVTZ 2011079-185, RVTZ 2011-079-335, RVTZ 2011-079-345 and RVTZ 2011-079503 are promising for improvements in achieving lines with background for processing, resistant to arthropod pests. Among them, we highlight that RVTZ 2011-079-117 represents an important technological breakthrough for tomato production, and is available for breeding programs which can be used in developing lineages.

\section{ACKNOWLEDGMENTS}

We thank Fundação Araucária de Apoio ao Desenvolvimento Científico e Tecnológico do Paraná for financial support, Conselho Nacional de Desenvolvimento Científico e Tecnológico (CNPq) for encouragement, and Coordenação de Aperfeiçoamento de Pessoal de Nível Superior (CAPES) for a Master's scholarship.

\section{REFERENCES}

ALBA, JM; MONTSERRAT, M; FERNÁNDEZMUÑOZ, R. 2009. Resistance to the twospotted spidermite (Tetranychusurticae) by acylsucroses of wild tomato (Solanum pimpinellifolium) trichomes studied in a recombinant inbred line population. Experimental and Applied Acarology 47: 35-47.

ATTIA, S; GRISSA, KL; LOGNAY, G; BITUME, E; HANCE, T; MAILlEUX, AC. 2013. A review of the major biological approaches to control the worldwide pest Tetranychus urticae (Acari: Tetranychidae) with special reference to natural pesticides. Journal of Pest Science 86: 361-386.

BALDIN, ELL; VENDRAMIM, JD; LOURENÇÃO, AL. 2005. Resistência de genótipos de tomateiro à mosca-branca Bemisia tabaci (Gennadius) biótipo B (Hemiptera: Aleyrodidae). Neotropical Entomology 34: 435-441.

CARTER, CD; SNYDER, JC. 1985. Mite responses in relation to trichomes of Lycopersicon esculentum x Lycopersicon hirsutum $\mathrm{F}_{2}$ hybrids. Euphytica 34: 177-185.

DIAS, DM; RESENDE, JTV; MARODIN, JC; MATOS, R; LUSTOSA, IF; RESENDE, NCV. 2016. Acyl sugars and whitefly (Bemisia tabaci) resistance in segregating populations of tomato genotypes. Genetics and Molecular Research 15: 1-11.

FERREIRA, DF. 2008. SISVAR: um programa para análises e ensino de estatística. Revista Cientifica Symposium 6: 36-41. 
FANCELLI, M; VENDRAMIN, JD; FRIGHETTO, RTS; LOURENÇÃO, AL 2005. Exsudato glandular de genótipos de tomateiro e desenvolvimento de Bemisia tabaci (Genn.) (Sternorryncha: Aleyrodidae) biótipo B. Neotropical Entomology 34: 59-665.

FIGUEIREDO, AST; RESENDE, JTV; MORALES, RGF; GONÇALVES, APS; SILVA, PR. 2013. The role of glandular and non-glandular trichomes in the negative interactions between strawberry cultivars and spidermite. Arthropod-Plant Interactions 7:53-58.

FREITAS, JA; MALUF, WR; CARDOSO, MG; OLIVEIRA, ACB. 2000. Seleção de plantas de tomateiro visando à resistência a artrópodes-praga mediada por zingibereno. Acta Scientiarum Agronomy 22: 919-923.

GAMEIRO, AH; CAIXETA FILHO, JV; ROCCO, CD; RANGEL, R. 2007. Estimativas de perdas no suprimento de tomates para processamento industrial no estado de Goiás. Informações Economicas 37: 07-16.

GONÇALVES, LD; MALUF, WR; CARDOSO, MG; RESENDE, JTV; CASTRO, EM; SANTOS, NM; NASCIMENTO, IR; FARIA, MV. 2006. Relação entre zingibereno, tricomas foliares e repelência de tomateiros a Tetranychus evansi. Pesquisa Agropecuária Brasileira 41: 267-273.

LIMA, IP; RESENDE, JTV; OLIVEIRA, JRF; FARIA, MV; DIAS, DM; RESENDE, NCV. 2016. Selection of tomato genotypes for processing with high zingiberene content, resistant to pests. Horticultura Brasileira 34: 387-391.

LIMA, IP; RESENDE, JTV; OLIVEIRA, JRF;
FARIA, MV; RESENDE, NCV; LIMA FILHO, RB. 2015. Indirect selection of industrial tomato genotypes rich in zingiberene and resistant to Tuta absoluta Meyrick. Genetics and Molecular Research 14: 1508115089.

LUCINI, T; FARIA, MV; ROHDE, C; RESENDE, JTV; OLVEIRA, JRF. 2015. Acylsugar and the role of tricomes in tomato genotypes resistence to Tetranychus urticae. ArthopodPlant Interactions 9: 45-53.

LUCINI, T; RESENDE, JTV; OLIVEIRA, JRF; SCABENI, CJ; ZEIST, AR; RESENDE, NCV. 2016. Repellent effects of various cherry tomato accessions on the two-spotted spider mite Tetranychus urticae Koch (Acari: Tetranychidae). Genetics and Molecular Research 15: 1-6.

MALUF, WR; CAMPOS, GA; CARDOSO, MG. 2001.Relationships between trichome types and spider mite (Tetranychus evansi) repellence in tomatoes with respect to foliar zingiberene contents. Euphytica 121: 73-80.

NEIVA, IP; ANDRADE JÚNIOR, VC; MALUF, WR; OLIVEIRA, CM; MACIEL, GM. 2013. Role of allelochemicals and trichome density in the resistance of tomato to whitefly. Ciência e Agrotecnologia 37: 61-67.

OLIVEIRA, CM; ANDRADE JÚNIOR, VC; MALUF, WR; NEIVA, IP; MACIEL, GM. 2012. Resistance of tomato strains to the moth Tuta absoluta imparted by allelochemicals and trichome density. Ciência e Agrotecnologia 36: 45-52.

RAKHA, M; BOUBA, I; RAMASAMY, S; REGNARD, JL; HANSON, P. 2017. Evaluation of wild tomato accessions
(Solanum spp.) for resistance to two-spotted spidermite (Tetranychus urticae Koch) based on trichome type and acylsugar content. Genetics Resources and Crop Evolution 64: 1011-1022.

SILVA, VF; MALUF, WR; CARDOSO, MG; GONÇALVES NETO, AC; MACIEL, GM; NÍZIO, DAC; SILVA, VA. 2009. Resistência mediada por aleloquímicos de genótipos de tomateiro à mosca-branca e ao ácaro-rajado. Pesquisa Agropecuária Brasileira 44: 12621269.

SILVA, FAS. ASSISTAT: Versão 7.7 beta. DEAGCTRN-UFCG - Actualyzed on April 01, 2014. Available at $<\mathrm{http}: / / \mathrm{www}$.assistat.com/>.

TOSCANO, LC; BOIÇA-JÚNIOR, AL; MARUYAMA, WI. 2002. Non-preference of whitefly for oviposition in tomato genotypes. Scientia Agrícola 59: 677-681.

UBIERNA, CV; IGLEZIAS, BD; NAVAS GRACIA, LM; RUIZ, GR; RUIZ, JLL; SÁNCHEZ, DA. 2010. La agricultura de precisión y lasTIC sem la recolección mecanizada de tomate. Vida Rural 312: 44-48. WESTON, PA; JOHNSON, DA; BURTON, HT; SNYDER, JC. 1989. Trichome secretion composition, trichome densities, and spider mite resistance of ten accessions of Lycopersicum hirsutum. Journal of the American Society for Horticultural Science 114: 492-498.

WESTON, PA; SNYDER, JC. 1990. Thumbtack bioassay: a quick method of measuring plant resistance to two spotted spider mites (Acari: Tetranychidae). Journal Economic Entomology 83: 500-504. 


\title{
Selection of potato clones for tuber yield, vine maturity and frying quality
}

\author{
Giovani O Silva'; ${ }^{1}$ Arione S Pereira ${ }^{2}$; Fernanda Q Azevedo²; Agnaldo DF Carvalho $^{3}$; Jadir B Pinheiro ${ }^{3}$
}

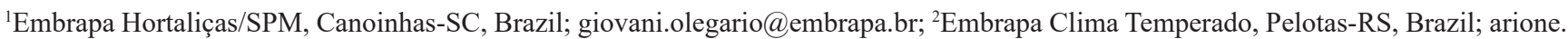
pereira@embrapa.br; fernanda.azevedo@embrapa.br; ${ }^{3}$ Embrapa Hortaliças, Brasília-DF, Brazil; agnaldo.carvalho@embrapa.br, jadir. pinheiro@embrapa.br

\begin{abstract}
Development of Brazilian potato cultivars adapted to different growing conditions, production systems and regions of the country is very important to increase the competitiveness of the national potato chain. In this sense, the objective of this work was to verify the performance of advanced potato clones for tuber yield traits, vine maturity and frying quality. An experiment was carried out in Pelotas-RS in spring, 2014. A set of nine advanced potato clones and two control cultivars were evaluated using a randomized complete block design with four replicates. Plots consisted of single rows of 20 plants spaced at $0.80 \mathrm{~m}$ between rows and $0.30 \mathrm{~m}$ between plants. The data of each trait were submitted to the deviance analysis, estimated the genetic values and selected the best genotypes using selection indices of the sum of ranks and the lowest distance from the ideotype. Clones F131-08-26 and F183-08-01, and the check 'Asterix' were distinguished for yield of marketable tubers. F183-08-01 and the control stood out for specific gravity and average tuber weight. Clone F161-07-02 ranked among the best for specific gravity, frying color and vine maturity. F97-07-04 and F183-08-01 and the check 'Asterix' were the best according to the selection indices, however, would result in losses in the frying color and vine maturity traits.
\end{abstract}

Keywords:Solanum tuberosum, selection index, genetic parameters.

\section{RESUMO}

Seleção de clones de batata para rendimento de tubérculos, ciclo vegetativo e qualidade de fritura

A obtenção de cultivares nacionais de batata adaptadas a diferentes condições de cultivo, sistemas e regiões do Brasil é muito importante para aumentar a competitividade da cadeia brasileira da batata. Neste sentido, o objetivo deste trabalho foi verificar o desempenho de clones de batata para caracteres de rendimento de tubérculos, ciclo vegetativo e qualidade de fritura. O experimento foi realizado em Pelotas-RS na primavera de 2014. Foi avaliado um conjunto de nove clones de batata e duas cultivares testemunhas, no delineamento experimental de blocos casualizados com quatro repetições e as parcelas constituídas de uma linha com 20 plantas, espaçadas em 0,80 m entre linhas e 0,30 m entre plantas. Os dados de cada caráter avaliado foram submetidos à análise de deviance. Foram estimados os valores genéticos e selecionados os melhores genótipos por índices de seleção da soma dos "ranks" e da menor distância ao tipo ideal. Para rendimento de tubérculos comerciais destacaram-se os genótipos F131-08-26, Asterix e F183-08-01, sendo os dois últimos genótipos também destaques para peso específico e massa média de tubérculos. O clone F161-07-02 foi classificado entre os melhores para peso específico, cor de fritura e ciclo vegetativo. Os clones F97-07-04 e F183-08-01 e a cultivar testemunha Asterix foram os melhores de acordo com os índices de seleção, que, no entanto, resultaria em perdas nos caracteres cor de fritura e ciclo vegetativo.

Palavras chave: Solanum tuberosum, índice de seleção, parâmetros genéticos.

\section{Received on June, 5, 2017; accepted on February 16, 2018}

$\mathrm{M}$ ost of the potato cultivars currently used in Brazil was developed in Europe. Because they do not have a good adaptation to Brazilian soil and climatic conditions, they require a high amount of inputs to reach high yields (Silva et al., 2014a). Therefore, the use of national cultivars adapted to the growing conditions of the different producing regions of the country is considered an important strategy to make the crop more productive and profitable to farmers (Silva et al., 2014a).
In temperate regions, potato cultivars with a later maturity ( $>130$ days) show higher yield in relation to the early ones, which is also true for tropical conditions (Silva \& Pinto, 2005; Rodrigues et al., 2009). However, farmers prefer early cultivars (Rodrigues et al., 2009) because they allow a greater number of crops per year and use of the area with other crops throughout the year, less time of plants exposure to adverse weather, lower risk of diseases and pests, and reduced demand for irrigation. In addition, these cultivars allow early harvesting of the crop to take advantage of good prices of the product on the market. Thus, earliness is a highly relevant trait for potato breeding programs, but it must be associated with tuber yield, among other traits.

The potato can be marketed in natura or used for industrial processing. Consumers give great important to tuber appearance, while processors require tuber traits that confer frying quality, like high specific gravity, low content of reducing sugars, besides absence of physiological disorders. 
The specific gravity is an important trait, because it is related as dry mass content in the tubers. Potatoes of high specific gravity yield more final product in industrialization, less absorption of fat during frying, besides influencing positively texture and taste. In turn, low sugar content prevents the darkening of processed products that compromise the appearance and taste of the fried product (Silva et al., 2014b).

The inferences about genetic materials in field experiments for classifying those clones to be released as cultivars should be based on true genotypic values, that is, on genotypic and non-phenotypic means. Genotypic means are future means, when cultivars will be grown as commercial crops. Since this prediction requires the true values of the variance components, it is important to use the best unplanned linear prediction (BLUP) and the maximum restricted likelihood (REML) methods. For this, the consideration of effects of treatments as random is essential, since only then genetic selection can be done, otherwise selection is phenotypic (Borges et al., 2010). Although when the experimental precision is adequate the phenotypic values are similar to the genotypic ones. However, in potatoes are still incipient studies using this theory.

In relation to the selection of superior genotypes for multiple traits, the selection process can be more efficient with the use of selection indexes, which allow combine multiple information from the experimental unit, so that selection is based on a complex of variables that gather several attributes of interest (Cruz et al., 2012). Several selection indexes have been described in the literature, being some based on the establishment of economic weights or desired gains for the traits. However, the difficulty and subjectivity to assign the necessary weights in the use of these methods, has led to the proposition of methods that exempt such determinations, such as the shortest distance in relation to the ideal genotype or ideotype and sum of the ranks (Cruz et al., 2012).

Silva et al. (2014b) evaluated the efficiency of selection index for yield components and frying quality, and found that the index of the shortest distance to the ideotype was superior to the other methods for identifying the best clones and obtaining higher gains.

Thus, the objective of this work was to verify the performance of advanced potato clones for tuber yield traits, vine maturity and frying quality.

\section{MATERIAL AND METHODS}

The experiment was carried out in Pelotas-RS $\left(31^{\circ} \mathrm{S}, 52^{\circ} \mathrm{W}, 50 \mathrm{~m}\right.$ altitude), in the 2014 spring season. Tubers were planted on August 26 and harvested 106 days later.

A set of nine advanced clones (F9707-04, F161-07-02, F110-07-01, F3708-01, F131-08-26, F156-07-19, F18308-01, CL310, and CL316) and two check cultivars (Agata: early maturity; Asterix: frying quality) were evaluated.

A randomized complete block design with four replicates was used. Plots consisted of single rows of 20 plants spaced at $0.80 \mathrm{~m}$ between rows and $0.30 \mathrm{~m}$ between plants.

Planting rows were fertilized with $3.8 \mathrm{t} \mathrm{ha}^{-1}$ of NPK commercial formula 05-30-10. Cultural and phytosanitary treatments followed the recommendations for the region (Pereira, 2010). Earthing up was done 30 days after planting, and no top-dressing of nitrogen was added.

Maturity of each plot was visually assessed 100 days after planting, using a nine-point scale (1-late, 9-early). Note 1 was ascribed for plots with plants showing the later green leaves and with less prostrated stems, and note 9 for plants with more yellowish leaves and stems prostrated, indicating proximity of vine maturity. For other plots intermediate grades were given, comparing with the two extremes, according to Silva et al. (2012).

After harvesting, tubers of each plot were graded as marketable (transversal diameter $>45 \mathrm{~mm}$ ) and non-marketable (transversal diameter $\leq 45 \mathrm{~mm}$ ), counted and weighed, for obtaining data of the following traits:

Marketable tuber yield $\left(\mathrm{kg} \mathrm{plot}^{-1}\right)$;

\section{Marketable tuber number;}

Average tuber weight (g), obtained by dividing the total tuber weight plot $^{-1}$ by the total tuber number.

The marketable tuber number and marketable tuber yield were converted to tuber number ha-1/1000 and marketable tuber ha-1 ${ }^{-1}$, respectively.

The specific gravity and chip color were also evaluated. The specific gravity was measured directly on the tubers using a hydrometer from the Snack Food Association (Kumar et al., 2007). The chip color was assessed using samples of 15 slices per plot, prepared from three medium and healthy tubers. Five 1-mm thick slices were cut transversally from the middle part of each tuber, washed in running water, dried with paper towel and sifted into vegetable oil at the initial temperature of $180^{\circ} \mathrm{C}$ until bubbling stopped. Color was assessed visually to a standard set on grading scale from 1 (dark) to 9 (light), adapted from Silva et al. (2014b).

The data of each trait were submitted to analysis of deviance and estimation of genetic parameters, genotypic values (phenotypic mean corrected by genetic values) and confidence intervals of genotypic values, using the REML/ BLUP method (Resende, 2002b). For the deviance analysis the following model was used:

$$
y=X r+Z g+e,
$$

where $y$ is the vector of observed data, $r$ is the vector of effects of repetitions (assumed as fixed), $g$ is the vector of genotypic effects (random), and $X$ and $Z$, incidence matrices for these effects (Resende, 2002a). As the number of genotypes was greater than ten, the effects of genotypes were considered as random, following the criterion of Resende \& Duarte (2007). Data analysis was done with SELEGEN software (Resende, 2002b).

The superior genotypes were selected by the index of the sum of ranks (Mulamba \& Mock, 1978), which consists of ranking genotypes for each trait in an order that favors breeding. The selection index based on the distance between each genotype and ideotype (Schwarzach, 1972 cited by Wricke \& Weber, 1986) was also used. This index is calculated using the least Euclidean 
distance of the ideal genotype, with the ideal genotype being the one with the maximum genotypic values for each trait. These analyzes were performed using the GENES software (Cruz, 2016).

\section{RESULTS AND DISCUSSION}

Deviance analysis revealed significant differences $(\mathrm{p}<0.05)$ among genotypes for all traits, indicating that there is difference in genotype performance for the evaluated traits (Table 1).

The phenotypic coefficient of variation $(\mathrm{CV})$ was lower for specific gravity, $0.29 \%$. The $\mathrm{CV}$ for the other traits varied from 7.76 to $19.59 \%$, for average tuber weight and chip color, respectively. These results indicate that, in this experiment, adequate experimental precision was obtained, considering that, for example, traits related to tuber yield, which is a quantitative trait, normally has a great influence on the environment (Silva et al., 2006).

The genotype $\mathrm{CV} /$ phenotype $\mathrm{CV}$ relationship was greater than 1 for all traits, indicating that genetic variation exceeded the environmental, and, therefore, selection for these traits could be efficient (Cruz et al., 2012). A large genetic effect on the phenotype can also be confirmed by the magnitudes of the genotypic variances in comparison to the phenotypic variances, by the accuracy in the selection, which exceeded $90 \%$ for all traits, and by the heritability coefficient in the broad sense. In the case of potato (asexual reproduction), the broad sense heritability exploits the additive, dominance and epistatic effects. This coefficient was not only elevated for the chip color trait (Table 1).

The appropriate experimental precision can also be attested by the mean of estimated heritability of the clones, or heritability to the genotypic mean, which was high for all the traits, being greater than or equal to $90 \%$, and indicated along with the selective accuracy, that high effectiveness with the selection can be obtained (Table 1). According to Resende (2002a), the accuracy value of the selection, which is the square root of the average heritability of the clones, indicates high precision in the inferences of the genotypic values, showing that the experimental conduction was appropriate for the identification of superior genotypes.

Observing the genotypic values, which refer to the values of the phenotypic means corrected by the genetic values corresponding to the predicted performance of the genotypes when they are cultivated, it was noted that for number and yield of marketable tubers, the clone F131-08-26 had the highest genotypic value, with potential mean yield of 193.32 marketable tubers $\mathrm{ha}^{-1} / 1000$ and $19.31 \mathrm{t} \mathrm{ha}^{-1}$ (Table 2).

For the marketable tuber number, clones F183-08-01, CL316, F97-0704, F161-07-02 and the check cultivar Asterix, belonging to the confidence interval of the best classified clone, with a lower limit of 163.90 tubers $\mathrm{ha}^{-1} / 1000$, stood out. For marketable tuber yield, the same genotypes, except F161-07-02, belonged to the confidence interval of the best clone.

The average marketable tuber number observed in this experiment (144.70 $\left.\mathrm{ha}^{-1} / 1000\right)$ is similar to that reported by Silva et al. (2012) (145.83 $\left.\mathrm{ha}^{-1} / 1000\right)$, who evaluated a set of eight advanced clones and check cultivars Agata and Asterix, in autumn conditions at the same location. For the marketable tuber yield the authors observed a mean value of $19.53 \mathrm{tha}^{-1}$, while in this study the mean was $13.97 \mathrm{t} \mathrm{ha}^{-1}$. Silva et al. (2014b) evaluated seven advanced clones and the same checks in the spring 2012 conditions in Canoinhas,

Table 1. Values of the likelihood ratio test (LRT) of deviance analysis and genetic parameters of the evaluation of 11 potato genotypes in Pelotas-RS, in spring 2014. Pelotas, Embrapa, 2018.

\begin{tabular}{lcccccc}
\hline Trait & MTN & MTY & ATW & SG & Color & MAT \\
\hline Genotype $^{1}$ & $32.57^{*}$ & $35.82^{*}$ & $38.03^{*}$ & $64.06^{*}$ & $23.68^{*}$ & $50.05^{*}$ \\
Genotypic variance & 1474.01 & 19.96 & 71.16 & 0.001 & 1.12 & 2.34 \\
Residual variance & 431.15 & 5.04 & 16.31 & 0.001 & 0.51 & 0.33 \\
Phenotypic variance & 1905.16 & 25.00 & 87.47 & 0.002 & 1.62 & 2.67 \\
Broad sense heritability & 0.77 & 0.80 & 0.81 & 0.92 & 0.69 & 0.88 \\
Average heritability of clones & 0.93 & 0.94 & 0.95 & 0.97 & 0.90 & 0.97 \\
Acuracy in the selection & 0.97 & 0.97 & 0.97 & 0.98 & 0.95 & 0.98 \\
CV genotypic (\%) & 26.53 & 31.98 & 16.22 & 1.02 & 29.04 & 26.82 \\
CV phenotypic (\%) & 14.35 & 16.07 & 7.76 & 0.29 & 19.59 & 10.03 \\
CV genotypic /CV phenotypic & 1.85 & 1.99 & 2.09 & 3.48 & 1.48 & 2.67 \\
General mean & 144.70 & 13.97 & 52.01 & 1.08 & 3.64 & 5.70 \\
\hline
\end{tabular}

${ }^{1}$ LRT values; Significant at *P= 0.01 by the $\chi^{2}$ test with one degree of freedom. MTN= marketable tuber number ha ${ }^{-1} / 1000 ;$ MTY $=$ marketable tuber yield in $\mathrm{t} \mathrm{ha}^{-1}$; $\mathrm{ATW}=$ average tuber weight in $\mathrm{g} \mathrm{tuber}^{-1} ; \mathrm{SG}=$ specific gravity, assessed directly using hydrometer; Color= frying color (notes of nine point scale, $1=$ light, $9=$ dark); MAT= vine maturity (notes of nine point scale, $1=$ late, $9=$ early). 
and found an average marketable tuber number of $114.43 \mathrm{ha}^{-1} / 1000$ and average marketable tuber yield of $21.00 \mathrm{t} \mathrm{ha}^{-1}$. Therefore, the experimental conditions of this experiment provided to the plants the adequate performance and similar to other studies with potato clones in the southern region of the country.

For average tuber weight, which is related to average tuber size, the clone F183-08-01, with $59.10 \mathrm{~g}^{\text {tuber }}{ }^{-1}$, only had no genotypic value higher than the check Asterix (69.41 $\mathrm{g}$ tuber $^{-1}$ ), with value included in the lower limit of the confidence interval for this cultivar. However, most of the other clones belonged to the same confidence interval as clone F183-08-01, except F37-08-01 and the check 'Agata', which presented the lowest genotype values, that is, smaller tubers. This indicates that the majority of the clones presents large tubers, highlighting the clone F18308-01, with sizes bigger than 'Agata', which is the most cultivated potato cultivar in the country.

In relation to vine maturity, clones F97-07-04 and F161-07-02 belonged to the same confidence interval of the check 'Agata', the earliest genotype, with note 7.92 . The later maturity clones were CL316, F131-08-26 and F183-0801 . In a study reported by Silva et al. (2012), in autumn, in Pelotas, 'Agata' had also the earliest maturity genotype of ten genotypes evaluated. It is worth noting that 'Agata', which presents a yellowish skin, is the most cultivated cultivar in the country, highlighting by early maturity combined with good- looking tubers (Fernandes et al., 2011; Peeten et al., 2011).

For traits related to frying quality, the clone F183-08-01 presented the highest specific gravity (1.105), but belonging to the same confidence interval of the estimated value for the check 'Asterix' (1.098), which is the main cultivar used for frying. However, the majority of the other clones, except F156-07-19 and check 'Agata', are in the same confidence interval of the values obtained for this check 'Asterix'. The specific gravity is highly correlated with the dry matter content, and it is a non-destructive trait of the samples and of easy and rapid evaluation (Bhering et al., 2009). Silva et al. (2012) verified specific gravity values of 1.082 for 'Asterix' and 1.062 for 'Agata'. Pinto et

Table 2. Predicted genotypic values $(u+g)$ and their lower (LIIC) and higher (LICS) confidence interval limits of the evaluation of 11 potato genotypes in Pelotas-RS, in spring 2014. Pelotas, Embrapa, 2018.

\begin{tabular}{|c|c|c|c|c|c|c|c|c|c|}
\hline \multirow{2}{*}{ Genotype } & \multicolumn{3}{|c|}{ NMT } & \multicolumn{3}{|c|}{ MMT } & \multicolumn{3}{|c|}{ ATW } \\
\hline & LIIC & $u+g$ & LSIC & LIIC & $u+g$ & LSIC & LIIC & $u+g$ & LSIC \\
\hline F97-07-04 & 131.87 & 161.29 & 190.71 & 13.02 & 16.35 & 19.68 & 50.26 & 56.45 & 62.64 \\
\hline F161-07-02 & 114.39 & 143.81 & 173.23 & 8.95 & 12.29 & 15.62 & 42.92 & 49.11 & 55.30 \\
\hline F110-07-01 & 72.65 & 102.08 & 131.50 & 6.76 & 10.09 & 13.42 & 41.56 & 47.75 & 53.94 \\
\hline F37-08-01 & 84.79 & 114.21 & 143.63 & 6.27 & 9.60 & 12.93 & 38.74 & 44.93 & 51.12 \\
\hline F131-08-26 & 163.90 & 193.32 & 222.74 & 15.98 & 19.31 & 22.64 & 49.66 & 55.85 & 62.04 \\
\hline F156-07-19 & 94.98 & 124.40 & 153.82 & 8.85 & 12.18 & 15.52 & 44.15 & 50.34 & 56.53 \\
\hline F183-08-01 & 156.62 & 186.04 & 215.46 & 15.27 & 18.61 & 21.94 & 52.91 & 59.10 & 65.29 \\
\hline CL310 & 97.89 & 127.31 & 156.73 & 8.91 & 12.25 & 15.58 & 42.50 & 48.69 & 54.88 \\
\hline CL316 & 138.18 & 167.60 & 197.02 & 13.78 & 17.11 & 20.44 & 46.24 & 52.43 & 58.62 \\
\hline Agata & 55.18 & 84.60 & 114.02 & 3.40 & 6.73 & 10.07 & 31.86 & 38.05 & 44.24 \\
\hline \multirow[t]{2}{*}{ Asterix } & 157.59 & 187.01 & 216.43 & 15.80 & 19.13 & 22.47 & 63.22 & 69.41 & 75.60 \\
\hline & \multicolumn{3}{|c|}{ SG } & \multicolumn{3}{|c|}{ Color } & \multicolumn{3}{|c|}{ MAT } \\
\hline F97-07-04 & 1.079 & 1.086 & 1.093 & 2.40 & 3.29 & 4.18 & 5.91 & 6.96 & 8.00 \\
\hline F161-07-02 & 1.081 & 1.088 & 1.095 & 3.75 & 4.64 & 5.52 & 5.91 & 6.96 & 8.00 \\
\hline F110-07-01 & 1.081 & 1.088 & 1.095 & 3.52 & 4.41 & 5.30 & 5.67 & 6.71 & 7.76 \\
\hline F37-08-01 & 1.079 & 1.086 & 1.093 & 5.10 & 5.98 & 6.87 & 5.43 & 6.47 & 7.52 \\
\hline F131-08-26 & 1.077 & 1.084 & 1.091 & 2.40 & 3.29 & 4.18 & 2.53 & 3.57 & 4.62 \\
\hline F156-07-19 & 1.068 & 1.075 & 1.083 & 2.18 & 3.07 & 3.95 & 5.43 & 6.47 & 7.52 \\
\hline F183-08-01 & 1.098 & 1.105 & 1.113 & 2.18 & 3.07 & 3.95 & 3.25 & 4.30 & 5.34 \\
\hline CL310 & 1.077 & 1.084 & 1.091 & 2.18 & 3.07 & 3.95 & 3.98 & 5.02 & 6.07 \\
\hline CL316 & 1.069 & 1.077 & 1.084 & 1.95 & 2.84 & 3.73 & 2.53 & 3.57 & 4.62 \\
\hline Agata & 1.053 & 1.061 & 1.068 & 1.73 & 2.62 & 3.50 & 6.88 & 7.92 & 8.97 \\
\hline Asterix & 1.084 & 1.091 & 1.098 & 2.85 & 3.74 & 4.63 & 3.74 & 4.78 & 5.83 \\
\hline
\end{tabular}

NMT $=$ number of marketable tubers per ha ${ }^{-1} / 1000 ;$ MMT $=$ mass of marketable tubers $t^{2} a^{-1} ; A T W=$ average tuber weight in $g^{-1} ; \mathrm{SG}=\mathrm{specific}$ gravity, assessed directly using hydrometer; Color= frying color (notes of nine point scale, $1=$ light, $9=$ dark); MAT= vine maturity (notes of nine point scale, $1=$ late, $9=$ early). 
al. (2010), on average of three locations in the south of Minas Gerais, reported value of 1.056 for 'Agata' and 1.073 for 'Asterix'. Asterix is a red skin cultivar most cultivated in the country and is widely used for processing into French fries because of its elongated tuber shape, relatively high dry matter content and light colored fries (Pereira et al., 2008).

For frying color, the highest genotypic value, that is, the lightest frying color, was obtained by clone F37-08-01, top mark, by the confidence limit, to the check 'Asterix'. Clones F161-07-02 and F110-07-01 were also within this range.

The search for early maturity clones and at the same time high yielder is a great challenge because, in general, late maturity genotypes tend to be more productive than the early ones (Silva \& Pinto, 2005; Rodrigues et al., 2009). Similarly, the selection of clones with high specific gravity and at the same time not too late is hampered by the existence of a positive relationship between later maturity and dry matter content in the tubers (Silva \& Pinto, 2005). This relationship probably occurs due to the longer time for photosynthesis, which can also lead to higher yield (Silva et al., 2012). Agreeing with this information, Pereira et al. (1994) found a negative correlation between early maturity, total and marketable tuber yield, and tuber size.

In this work, in general, the vine maturity and frying color were positively related, indicating a situation favorable to the selection, and that lighter frying color materials would be of early maturity. An example of it is the selection of clone F161-07-01 among the best for both traits. Pereira et al. (1994) found a correlation between early maturity and lighter frying color, which was also verified by Pereira \& Campos (1999). This relationship probably occurs because, for very late genotypes, at the harvest time tubers may still be immature, with a higher concentration of reducing sugars (Pereira \& Campos, 1999), which have not yet been converted into starch. This positive relationship between better frying color and higher specific gravity was also observed in other studies (Pereira et al., 1994; Pereira \& Campos, 1999; Bisognin et al., 2008).

For the relationship between the yield traits with frying quality traits, in this study it was possible to identify clones with high tuber yield and high specific gravity, but the same did not be true for high yield and good frying color. Bisognin et al. (2008) did not find significant associations between yield traits and frying quality traits. Likewise, Pereira \& Campos (1999) concluded that there was no strong association between the reducing sugar content and yield traits, because in such study the associations were negative, but not significant.

Rodrigues \& Pereira (2003), based on low magnitude correlations between frying quality and yield traits, concluded that the selection for both in relation to the frying color and the dry matter content would affect little the tuber yield of the sample population plants of selected clones. However, Terres et al. (2012) verified a correlation of low magnitude $(\mathrm{r}=0.19)$, but significant, between the total tuber yield and the color, while Pereira et al. (1994) found a negative correlation between frying color and total yield and tuber size. This relationship between tuber yield, specific gravity and frying color also seems to be related to the vine maturity, since the later genotypes tend to be more productive and to accumulate more dry matter, but at an earlier harvest they tend to present higher reducing sugar. However, this relationship can be more or less evidenced depending on the set of genotypes evaluated, and other variables, such as length of photoperiod and temperature during the growing period. In a shorter photoperiod, the maturity is early (Rodrigues et al., 2009) and under lower temperatures the sugar content is higher (Pereira \& Campos, 1999).

The selection index allow the joint selection for the traits, i.e., the identification of the best genotypes for all the traits together. According to the index of selection of the lowest genetic distance to the ideotype, and also to the index based on the sum of ranks, the genotypes that best aggregated all the evaluated traits were clones F9707-94 and F183-08-01, and the check 'Asterix'. In the comparison with the genotypes with the best performance for each trait, based on the genotypic values, the clone F183-08-01 and the check'Asterix' stood out mainly for the tuber yield traits and specific gravity; while F97-07-94 stood out for the traits average tuber weight and vine maturity; and 'Asterix' and F97-07-94 had genotypic values close to the three best genotypes for the frying color (Table 2).

Using selection indexes, which provide the possibility of selecting both for higher yield, shorter cycle and higher frying quality, these three genotypes (F183-08-01, F97-07-94 and check 'Asterix') present predicted genotypic values higher than the overall mean, in $23.09,29.06,18.54$ and $0.92 \%$ for marketable tuber number, marketable tuber yield, average tuber weight, and specific gravity, respectively. However, there would be losses for the frying color $(-7.50 \%)$ and vine maturity $(-6.20 \%)$ traits. That is, there would be gains in yield of marketable tubers and specific gravity, but losses in the order of 6 to $7 \%$ in the frying color and of vine maturity.

So, clones F131-08-26 and F18308-01 stand out in yield of marketable tubers, specific gravity and average tuber weight. F161-07-02 ranks among the three best clones for specific gravity, frying color and vine maturity. Clones F97-07-04 and F183-08-01 and check 'Asterix' showed to be the best according to index of selection, which, however, would result in losses in frying color and vine maturity traits.

\section{REFERENCES}

BHERING, LL; PINTO, CABP; BENITES, FRG; LEITE, ME; SILVA, FL. 2009. Seleção assistida por marcadores para teor de matéria seca e açúcares redutores em tubérculos de batata. Ciência Rural 39: 38-44.

BISOGNIN, DA; COSTA, LC; ANDRIOLO, JL; MÜLLER, DR; BANDINELLI, MG. 2008. Produtividade e qualidade de tubérculos de clones de batata. Ciência e Natura 30: 43-56.

BORGES, V; FERREIRA, PV; SOARES, L; SANTOS, GM; SANTOS, AMM. 2010. Seleção de clones de batata-doce pelo procedimento REML/BLUP. Acta Scientiarum 
Agronomy 32: 643-649.

CRUZ, CD. 2016. Genes Software-extended and integrated with the R, Matlab and Selegen. Acta Scientiarum Agronomy 38: 547-552.

CRUZ, CD; REGAZZI, AJ; CARNEIRO, PCS.2012. Modelos biométricos aplicados ao melhoramento genético. Viçosa: Editora UFV. 514p.

FERNANDES, AM; SORATTO, RP; EVANGELISTA, RM; SILVA, BL; SOUZASCHLICK, GD. 2011. Produtividade e esverdeamento pós-colheita de tubérculos de cultivares de batata produzidos na safra de inverno. Ciência Agronômica 42: 502-508.

KUMAR, P; PANDEY, S; SINGH, B; SINGH, S; KUMAR, D. 2007. Influence of source and time of potassium application on potato growth, yield, economics and crisp quality. Potato Research 50: 1-13.

MULAMBA, NN; MOCK, JJ. 1978. Improvement of yield potential of the Eto Blanco maize (Zea mays L.) population by breeding for plant traits. Egyptian Journal of Genetics and Cytology 7: 40-51.

PEETEN, MGH; FOLKERTSMA, S; SCHIPPER, JK; BAARVELD, HR; KLEIN, S. 2011. Netherlands Catalogue of Potato Varieties. The Hague: NIVAP. 285p.

PEREIRA, AS; TAI, GCC; YADA, RY; TARN, TR; SOUZA-MACHADO, V; COFFIN, RH. 1994. Effect of selection for chips colour on some economic traits of potatoes. Plant Breeding 113: 312-317.

PEREIRA, AS; CAMPOS, A. 1999. Sugar content in potato (Solanum tuberosum L.) genotypes.
Ciência Rural 29: 13-16.

PEREIRA, AS (org). 2010. Produção de batata no Rio Grande do Sul. Sistema de Produção, 19. Pelotas: Embrapa Clima Temperado. 95p.

PEREIRA, AS; NEY, VG; TERRES, LR; TREPTOW, RO; CASTRO, LAS. 2008. Caracteres de produção e qualidade de clones de batata selecionados de população segregante para resistência ao vírus $Y$ da batata. Boletim de Pesquisa e Desenvolvimento, 67. Pelotas: Embrapa Clima Temperado. 18p.

PINTO, CABP; TEIXEIRA, AL; NEDER, DG; ARAÚJO, RR; SOARES, ARO; RIBEIRO, GHMR; LEPRE, AL. 2010. Potencial de clones elite de batata como novas cultivares para Minas Gerais. Horticultura Brasileira 28: 399-405.

RESENDE, MDV. 2002a. Genética biométrica e estatística no melhoramento de plantas perenes. Brasília: Embrapa Informação Tecnológica. 975p.

RESENDE, MDV. 2002b. Software Selegen REML/BLUP. Curitiba: Embrapa Florestas. $67 \mathrm{p}$.

RESENDE, MDV; DUARTE, JB. 2007. Precisão e controle de qualidade em experimentos de avaliação de cultivares. Pesquisa Agropecuária Tropical 37: 182-194.

RODRIGUES, AFS; PEREIRA, AS. 2003. Correlações inter e intragerações e herdabilidade de cor de chips, matéria seca e produção em batata. Pesquisa Agropecuária Brasileira 38: 599-604.
RODRIGUES, GB; PINTO, CAB; BENITES, FRG; MELO, DS. 2009. Seleção para duração do ciclo vegetativo em batata e relação com a produtividade de tubérculos. Horticultura Brasileira 27: 280-285.

SILVA, LAS; PINTO, CABP. 2005. Duration of the growth cycle and the yield potential of potato genotypes. Crop Breeding and Applied Biotechnology 5: 20-28.

SILVA, GO; SOUZA, VQ; PEREIRA, AS; CARVALHO, FIF; FRITSCHE-NETO, R. 2006. Early generation selection for tuber appearance affects potato yield components. Crop Breeding and Applied Biotechnology 6: 73-78.

SILVA, GO; CASTRO, CM; TERRES, LR; ROHR, A; SUINAGA, FA; PEREIRA, AS. 2012. Desempenho agronômico de clones elite de batata. Horticultura Brasileira 30: 557-560.

SILVA, GO; BORTOLETTO, AC; PONIJALEKI, R; MOGOR, AF; PEREIRA, AS. 2014a. Desempenho de cultivares nacionais de batata para produtividade de tubérculos. Ceres 61: 752-756.

SILVA, GO;PEREIRA, AS; CARVALHO, ADF. 2014b. Seleção de clones de batata para fritura com base em índices de seleção. Ceres 61: 941-947.

TERRES, LR; NEY, VG; CERIOLI, MF; PEREIRA, AS; TREPTOW, RO. 2012. Respostas esperadas de seleção para cor de fritura em quatro populações híbridas de batata. Horticultura Brasileira 30: 300-303.

WRICKE, G; WEBER, EW. 1986. Quantitative genetics and selection in plant breeding. Berlin: Walter de Gruyter. 406p. 